University of San Diego

Digital USD

2008-05-01

\title{
Private and Public University Students' Perceptions of Cultural Adjustment Problems in Study Abroad Programs
}

Walter R. Heinecke EdD

University of San Diego

Follow this and additional works at: https://digital.sandiego.edu/dissertations

Part of the Leadership Studies Commons

\section{Digital USD Citation}

Heinecke, Walter R. EdD, "Private and Public University Students' Perceptions of Cultural Adjustment Problems in Study Abroad Programs" (2008). Dissertations. 783.

https://digital.sandiego.edu/dissertations/783

This Dissertation: Open Access is brought to you for free and open access by the Theses and Dissertations at Digital USD. It has been accepted for inclusion in Dissertations by an authorized administrator of Digital USD. For more information, please contact digital@sandiego.edu. 


\title{
PRIVATE AND PUBLIC UNIVERSITY STUDENTS' PERCEPTIONS \\ OF CULTURAL ADJUSTMENT PROBLEMS IN \\ STUDY ABROAD PROGRAMS
}

\author{
by \\ WALTER R. HEINECKE \\ A dissertation submitted in partial fulfillment \\ of the requirements for the degree of \\ Doctor of Education \\ University of San Diego
}

May 2008

Dissertation Committee

Fred J. Galloway, Ed.D.

Robert Donmoyer, Ph.D.

James B. Gerber, Ph.D. 
(C) Copyright by Walter R. Heinecke 2008

All Rights Reserved 


\begin{abstract}
In a world that is increasingly integrated by economics, communications, and politics, higher education is asked to deliver graduates who can function professionally in the international arena. One way to do this is through study abroad programs, which have skyrocketed in popularity among American students over the last 15 years, increasing by $83 \%$ to more than 205,000 students in 2007.

Despite the obvious benefits associated with such programs, there are challenges to living abroad as well—especially for young adults. To get some sense of these challenges, during the 2005-2006 academic year 114 study abroad students from 2 Southern California universities ( 1 public, 1 private) completed 2 modified versions of the Michigan International Student Problem Inventory containing more than 100 questions-once prior to departure when they were asked to rate their level of expected problems in 9 general areas, and then again when they returned to the United States at the completion of their study abroad experience. By comparing the actual level of problems experienced in these areas to predeparture expectations, students were found to have both expected and largely experienced nothing more than minor problems, although their expectations in all 9 areas consistently exceeded the reality of their experience. Specifically, predeparture expectations suggested that in 7 of the areas students only expected minor problems while in the other 2 areas-religious services and student activities - students anticipated no problems at all. Upon their return, students consistently reported fewer problems than expected; 6 areas were classified as no problem and 3 as minor (led by social-personal). Additionally, in 8 of the problem areas
\end{abstract}


the expectations of students at the public university were closer to reality than those at the private university.

Taken together, these results suggest that while the problems experienced during the study abroad experience may have only been minor, administrators can still do a better job of helping to align expectations with reality. Based on focus group interviews this can be done in at least 3 ways: expanded orientation activities, better tracking of country-specific student problems, and through the matching of returning students with similar experiences. 


\section{ACKNOWLEDGEMENTS}

This has been a long and interesting journey. I wish to express my deep gratitude to my advisor and committee chairman, Dr. Fred Galloway. His patience, guidance, and advice inspired me throughout all of my graduate studies. Without his enthusiastic assistance, this project would not have been possible. I am also deeply indebted to my committee members, Dr. Bob Donmoyer and Dr. Jim Gerber, whose talents and insights influenced the content of this project.

I also wish to thank Bill Clabby for providing me access to his study abroad students, Andrea Saltzman for her SPSS guidance, Jen Freimund and Chelsea Stautman for their help with statistics, Susanne Strauss for her editing, and Laura Goldstein for her assistance with the presentation. Yvette Fontaine deserves recognition for giving me the idea for this project. I am also grateful to my many students who provided me the motivation and data for this dissertation.

I am also very grateful to Dr. Christopher Edginton who introduced me to higher education and whose inspiration was the driving force in my motivation this doctoral degree.

Last but not least, many thanks to my wife, Meredith, whose encouragement and sacrifice over these many years allowed me to complete the journey. All of this proves, once again, that you are never too old to be a student. 


\section{TABLE OF CONTENTS}

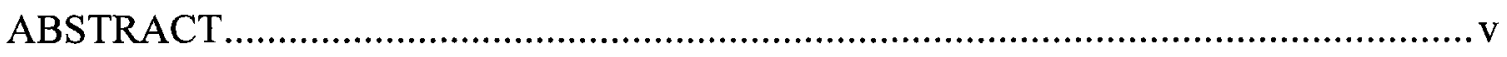

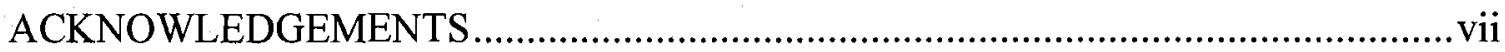

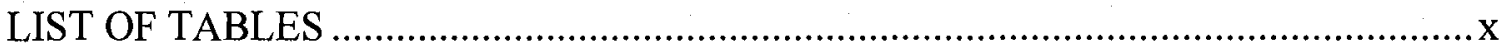

\section{CHAPTER}

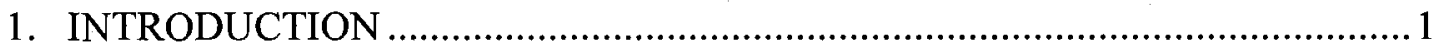

Statement of the Problem ..................................................................... 5

The Purpose of the Study................................................................ 6

The Research Questions .............................................................6 6

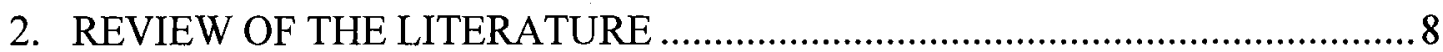

Introduction............................................................................... 8

The Effect of 9/11 on Study Abroad ................................................... 11

The Study of Culture Shock ............................................................. 12

Reentry Adjustments .................................................................. 15

Study Abroad Student Issues ...................................................... 15

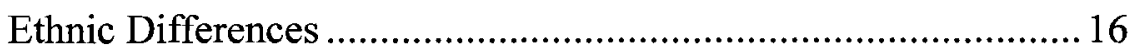

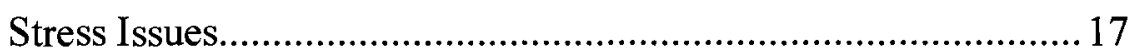

The Michigan International Student Problem Inventory..................... 18

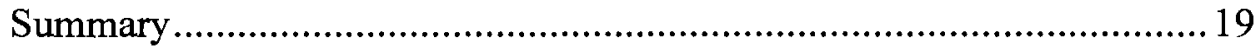

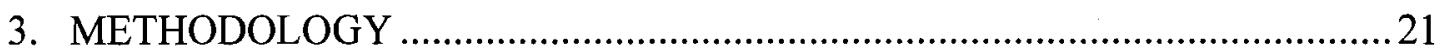

The Participants and the Programs...................................................... 21

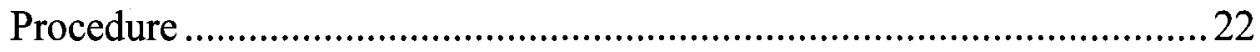

Phase 1: Departure Questionnaire ........................................ 23

Phase 2: Reentry Questionnaire ......................................... 23

Phase 3: Focus Groups....................................................... 24

Data Analysis ....................................................................... 24

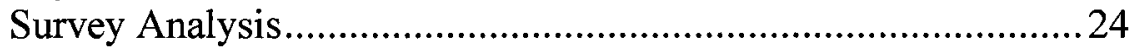

Summary of Analyses............................................................2 24

Analyses of the Focus Groups..............................................25

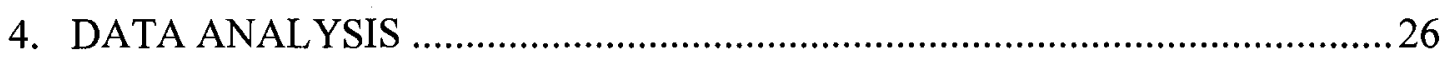

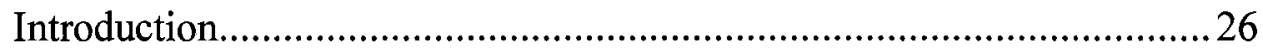

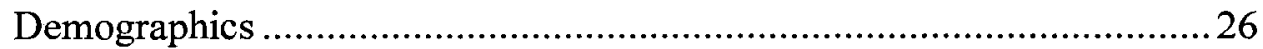

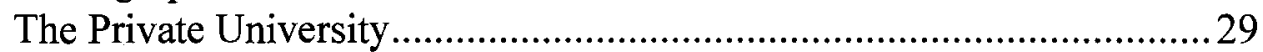

The Public University..................................................................... 30

Data Analysis .................................................................. 32

A Final Issue Regarding Sample Size .......................................... 40 
5. THE FINDINGS AND CONCLUSIONS....................................................56

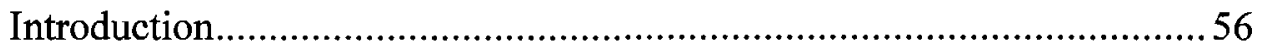

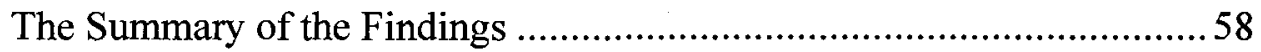

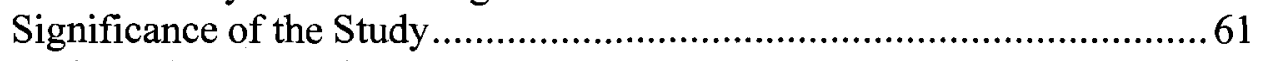

Delimitations and Limitations ........................................................62

Implications and Applications of Future Studies................................6 64

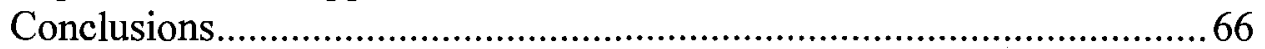

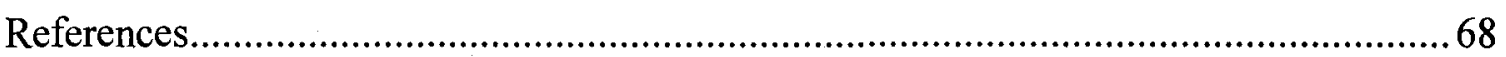

Appendix

A. Michigan International Student Problem Inventory ..................................... 72

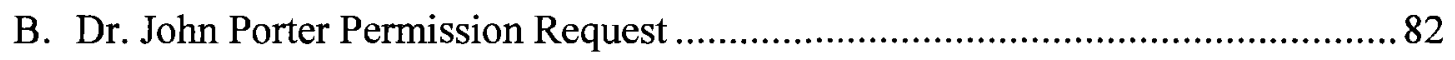

C. Dr. John Porter Permission Letter ............................................................... 84

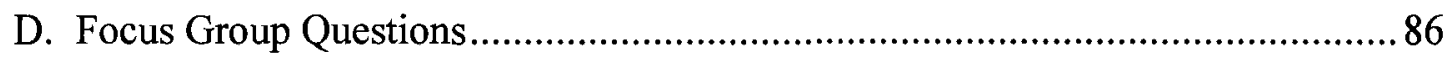

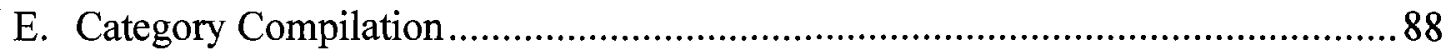

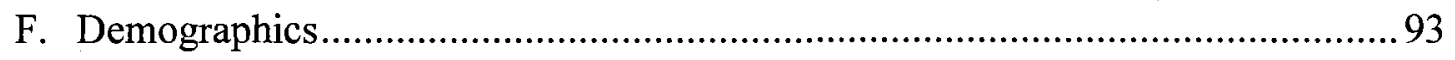




\section{List of Tables}

Table 1. Sample Demographics for the Study Abroad Participants..............................27

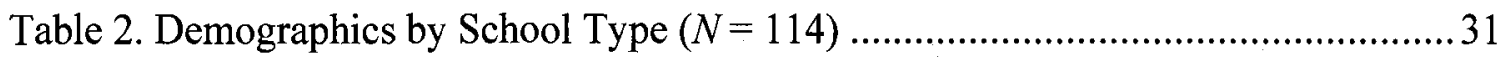

Table 3. Mean Score (in Descending Order) for Nine Potential Problem Areas by University

Table 4. Top Concerns Predeparture Within Each Category

Table 5. Major Concerns Reported Predeparture (in Descending Order) 38

Table 6. Significant Differences in Variables Between Private and Public University

Study Abroad Students Predeparture 39

Table 7. Mean Rankings of Categories Upon Reentry (in Descending Order)

Table 8. Top Concerns Upon Reentry According to Category.

Table 9. Significant Differences in Variables Between Private and Public University

Study Abroad Students Upon Reentry

Table 10. Major Expectations Upon Reentry (in Descending Order). .46

Table 11. Overall Mean Change Rankings of Categories Indicating Change in Expectations of the Reentry Survey From the Predeparture Survey .48

Table 12. Differences in Category Issues Predeparture and Reentry 


\section{CHAPTER 1}

\section{INTRODUCTION}

In a world increasingly integrated by economics, communications, and politics, higher education is asked to deliver graduates who are competent not only to function professionally in an international environment, but who are equipped to make personal and public policy decisions as citizens of an international society (Pickert, 1992). To assist higher education in its efforts to meet this challenge, federal and private agencies have allocated increased recourses for international education programs. In particular the National Security Act (NSEA), signed into law in December 1991, set aside funding for three program areas: (a) undergraduate study abroad, (b) graduate fellowships for students who commit to government service or teaching, and (c) institutional support for foreign language and international studies in higher education (Voght \& Schaub, 1993).

With this sort of encouragement, study abroad programs have become common place within higher education. According to statistics provided by the Institute of International Education, the number of U.S. students who study abroad each year has increased $80 \%$ over the last 15 years to over 205,000 (Hey-Kyung, 2006). Student destinations have shifted as well, with growing numbers of American students studying in non-Western countries (e.g., China, Russia, and Vietnam; Saltzman \& Mulrine, 1996).

Learning opportunities provided by study abroad programs are extensive. The majority of study abroad programs are offered for entire semesters, although certain university programs are offered for summer sessions, or for the entire academic year (Hey-Kyung, 2006). Students who take advantages of these opportunities may gain independence, patience, maturity, and increased tolerance for different values and 
lifestyles, as well as a perspective of varying cultures, politics, and economies (Green, 2000). This cultural learning is considered to be the product of cross-culture adaptation by the student. It includes for them new ways of living that include perhaps different values, standards, behavioral norms, patterns of thinking, and varying communications styles that are developed though the study abroad experience (Hess, 2002). These qualities, in turn, might make such students more attractive to potential employers after graduation (Green \& Olson, 2003).

Unfortunately, the many positive aspects of living abroad are often accompanied by difficulties that may become debilitating. The term for this is "culture shock," which was coined by the anthropologist Karl Oberg (1960) who explained both the symptoms and the process of adapting to a different culture. The experience of a new culture is seen as an unpleasant surprise-a shock that occurs when reality does not coincide with expectations. Individuals seeking new academic or career opportunities abroad find that everyday situations, such as social events, meals, and shopping, suddenly include major obstacles that must be overcome before normal, everyday tasks can be successfully accomplished. Although most of these individuals are highly skilled in their own society, they often times find themselves inadequate in their new environment.

It is not just American students studying abroad who experience culture shock and its negative consequences. Sojourners of all sorts experience varying degrees of frustration and distress. In a comprehensive literature review, Jenkins (2001) reported that $15 \%-25 \%$ of foreign students studying in the United States have significant adjustment difficulties. Church (1982) reported that approximately 33\% of American families with overseas assignments experience so many problems that some family 
members must return home prematurely, and 35\%-40\% of Peace Corps volunteers quit their service in order to return home before their assignment is completed.

Some American students traveling abroad may not anticipate the amount of personal effort and creativity needed to make their time spent abroad a positive experience. The literature quotes students who describe their anger, frustration, discouragement, and depression in the first weeks of their study abroad experience (Kauffmann, Martin, \& Weaver, 1992). Positive and enthusiastic descriptions from study abroad program directors and returning students may cause students to alternate between blaming themselves (leaving them feeling depressed, discouraged, and guilty) and blaming aspects of the situation (directing anger towards program coordinators, host family members, locals, or other students) when their experiences abroad do not match their expectations. Peace Corps volunteers and people pursuing careers overseas usually have at least 2 years to adjust to a new assignment. However, students studying abroad usually have only a few months during which to adapt to their new surroundings and achieve their goals. Students who cannot adjust under such tight time limits are left with lingering questions about their time abroad.

When students return home, they often face additional difficulties as they struggle to readjust to their previous surroundings. Part of the difficulty may be a matter of expectations. Westwood, Lawrence, and Paul (1986) suggested that reentry may in fact be more troublesome than culture shock, as sojourners anticipate that some adjustment will be necessary when entering a foreign culture. Rarely do students expect difficulties upon their return home. 
Students who travel to developing countries may be especially impacted by their experiences abroad; such travel experiences often require months or even years of reassessing personal values and goals (Lewis, 2003). Even students who travel to cultures that are quite similar to U.S. culture often seem to experience some disorientation as they readjust to the daily life in the United States. When students were asked to describe what reverse culture shock meant to them, a student who had returned from France replied that the readjustment for returning home was equally as difficult as the adjustment to the host country experience (Raschio, 1987).

Another difficult aspect of reentry for returning students is a relative lack of social support or evident resources designed to help students readjust to their home environment. In contrast with the host country entry process, which is likely to be highly structured with specific arrival dates, onsite orientation, and support from program coordinators, the reentry process is rather nebulous. Students generally return to the United States while school is not in session. They may stay with friends or family, start a summer job, or take a semester off from school. In most cases, they will not have the opportunity to interact with other study abroad students or support staff during their initial period of reentry.

A second important difference in the nature of the social support available during entry and reentry may be due to differences between host and home family environments. During their semester abroad, students are often placed with families who have hosted American students for many years. Such families are usually up to date on American pop culture and politics and may have a number of resources available to help American students to bridge the gap between their home environment and the host culture's 
environment. One student described her experience with her French host family as follows: "They'd had Americans in their house for the past ten years. They were patient and they had so many books; they were very helpful"' (Kauffmann et al., 1992, p. 21). Even students who return to a warm and supportive family may experience some frustration if they perceive that their own family does not have the resources or experience to understand their international experiences (Raschio, 1987).

\section{Statement of the Problem}

Although international travel and opportunities to work or study abroad are not new, relatively little is understood about the acculturation processes that study abroad students undergo. The problem is that there is limited research available that creates realistic expectations for study abroad students prior to their travel, while studying in the country, and for coping with reentry upon their return home. Much of the literature in this area is long on theory and prescriptions while short on data (Marx, 2001).

A review of the literature indicates that there are inadequacies in the research on the effect of cultural adaptation for U.S. students who experience study abroad learning. A review from the University of San Diego (USD) electronic databases to include ERIC as well as a search of the San Diego circuit of combined university holdings of USD, University of California at San Diego (UCSD), San Diego State University (SDSU), and California State University (CSU) at San Marcos give no evidence of survey studies for the study of either culture shock, culture adaptation, or reentry issues for students who have experienced study abroad. The bulk of the literature addresses a broad view of methods for adjusting to various countries and cultures. There are also studies available 
that measure the adaptation of foreign students who study in the United States (Galloway \& Jenkins, 2005).

In light of the potential for study abroad experiences to provide both uniquely positive and quite negative experiences for students, it is important to conduct research that helps us understand how students adjust to foreign cultures, how the experience affects them, and how they seek to integrate and build upon that experience after their return.

The Purpose of the Study

The purpose of this study was to collect information on the expectations of the acculturative process for students prior to their departure for study abroad and the reality of their expectations upon their reentry (return) to the United States. Specifically, this study measured both the anticipated and the actual problems experienced by study abroad students and then compare expectations with reality. The study also examined some of the reentry difficulties experienced by students as they return to the United States. By following the cross-cultural experience, using quantitative and qualitative measures, the results of this study will hopefully be able to fill in some of the gaps in our knowledge.

The Research Questions

This study endeavored to answer the following research questions:

1. What kinds of adjustment problems do study abroad students anticipate prior to their departure for study abroad?

2. What are the problems experienced during the study abroad experience? 
3. To what extent are the student's expectations regarding problems actually realized?

4. What kinds of adjustment challenges are experienced upon reentry? 


\title{
CHAPTER 2
}

\section{REVIEW OF THE LITERATURE}

\author{
Introduction
}

The literature points to the 1957 Soviet Union launching of Sputnik, the world's first satellite, as the event that served as an impetus for dramatic changes in the educational focus of the United States. This event caused educators to look beyond our borders. The quest for international travel goes back nearly 100 years before when the author Mark Twain wrote that "travel is fatal to prejudice, bigotry, and narrowmindedness and many of our people need in sorely on these accounts. Broad, wholesome, charitable views of men and things cannot be acquired by vegetating in one little corner of the earth all one's lifetime" (Twain, 1869, p. 12).

The passage of the National Defense Education Act by the 85th Congress led the way for increased international study. This act acknowledged the nation's need to confront serious deficiencies in many fields, including the training of scientists, the production of military might, and the U.S. citizen's understanding of international relations as it pertained to geography and foreign language. The National Defense Education Act proclaimed:

It is no exaggeration to say that American's progress in many fields of endeavor in the years ahead, in fact the very survival of our free country may depend in large part upon the education we provide for our young people now. (Voght \& Schaub, 1993, p. 44)

As evidence of the inability of the United States to communicate with foreign audiences, the Act noted that only $15 \%$ of all college students were studying a foreign language. To rectify the concern regarding foreign language learning, the Defense Education Act (DEA) approved the establishment of foreign language learning centers at 
universities around the country and the enhancement of the study of geography, history, and economics. Underpinning this initiative was the presumption that through language acquisition and geographic awareness, cross-cultural understanding is acquired.

Fitzgerald (1998) argued that by reviewing U.S. history books at the time the DEA was passed, one could gather that foreign policy became important to the United States in the 1950

Another impetus for study abroad was the growing interest in global awareness that resulted from the Cold War; specifically, the need was for diplomats with language skills. One of the results of this interest was the creation of the National Resource Center, which was established in 1965, for the purposes of language and area studies by the U.S. Department of Education, jointly with the Latin American, Caribbean, and Iberian studies program the University of Wisconsin-Madison (National Resource Center, 2008). The program provides grants to establish, strengthen, and operate language and area studies centers that are national resources for teaching any modern foreign language. Their grants support: instruction in fields needed to provide full understanding of areas, regions, or countries; research and training in international studies; work in the language aspects of professional and other fields of study; and instruction and research on issues in world affairs. Today, the National Resource Center program covers multiple centers for Asian, African, and European studies as well as over 20 Latin American centers.

In the 1980 s, our national fears about declining competitiveness resulted in the Omnibus Trade and Competiveness Act of 1988 and the establishment of the Center for International Business Education and Research (CIBER). CIBER (2008) also helps to increase and promote the nation's capacity for international understanding and economic 
enterprise. Administered by the U.S. Department of Education under Title VI, Part B, of the Higher Education Act of 1965, the CIBER network links the manpower and technological needs of the U.S. business community with the international education, language training, and research capacities of universities across the country. The 31 centers serve as regional and national resources to business people, students, and teachers at all levels.

For the past 50 years, millions of federal dollars have been earmarked for schools by the National Defense Educational Act to enhance students' understanding of foreign languages, geography, and international relations. However, this has not led to higher levels of student performance in these subjects (Kirwan, 2004). For example, in 1988, the National Geographic Society tested the knowledge of school-age students from a variety of countries on the subject of world geography. It ranked the United States in the bottom third. The questions asked in 1988 were the same asked in 1957 and the results were no better. In fact, the results might be considered worse if one adjusted for advancements in education (Grosvenor, 1988).

Recent research further validates Grosvenor (1988). Diana Oblinger (2002), the Microsoft Director of Higher Education, noted that less than 7\% of U.S. college students meet the basic standards for global preparedness. She further stated that only $1 \%$ of U.S. college students study abroad. Oblinger defined "global preparedness" in the American Council of Education (ACE) 1988 report that noted that to become globally competent, one must have four or more international college courses and have an unspecified ability to speak a foreign language. 
The Effect of 9/11 on Study Abroad

Several scholars have suggested that the aggression on September 11, 2001, caused a national mindset alteration similar to Sputnik in 1957. In The Chronicle of Higher Education, J. D. Edwards, the Executive Director of the Joint National Committee for Languages, suggested that the attack could lead to improved national security through the creation of academic programs designed to increase international understanding (Hebel, 2002). Richard Brecht, Director of the National Foreign Language Center at the University of Maryland, also saw a paradigm shift, stating "On September 11, the world did not change at all. Our understanding of the world did" (Hebel, 2002, p. 48). The study by Bikson, Treverton, Moini, and Lindstrom (2003) contended that the need for a globally competent workforce was not for the government alone, suggesting that corporations, nongovernmental institutions, and intergovernmental organizations have had the need to hire globally competent employees. While unstated in the Bikson et al. study, institutions of higher learning clearly must play an essential role in preparing agile, flexible workers for international positions.

U.S. college students have begun to demand more globally focused courses. Germann and Krupar (2002) observed that after September 11, there was an immediate longing for international knowledge among U.S. college students. An interest in courses emphasizing international education is growing.

The National Association of Foreign Student Advisors (NAFSA), the Association of International Educators, reasoned that international education has been set back considerably as a result of the fallout from the events of September 11. Before that date, a strong national consensus on the value of international education and academic exchange 
for the United States had existed for more than 50 years (NAFSA, 2003). NAFSA's conclusions are based on the construction of the availability of student visas, which follow foreign students' study in the United States. Conversely, there is growing concern by U.S. students about their safety and security while studying abroad. There are data currently available to support that students are studying abroad at a greater rate. In the first full academic year after the 9/11 attacks (academic year 2002/2003), the number of U.S. higher education students receiving credit for study abroad increased sharply by $9.5 \%$ from the previous year, reaching a record total of 174,200 , according to the Open Doors Annual Report on International Education Exchange for 2006. By the academic school year of 2004/2005, the study abroad numbers increased to 205,983 students (HeyKyung, 2006).

The Study of Culture Shock

Karl Oberg (1960) first defined the term culture shock as a sense of anxiety or distress experienced by foreigners as a result of losing all the familiar signs or cues of social interaction in daily life. For Oberg, any attempt to prevent or alleviate culture shock would emphasize knowledge of the correct social skills in the new culture.

Soon after Oberg's (1960) introduction of the term, many social scientists suggested that culture shock involves an adjustment process that sojourners must face as result of sudden change. The adaptation process is postulated to resemble a $\mathrm{W}$-shaped curve: Psychological adjustment across time is marked by an initial stage of elation, followed by confusion and depression, and gradual improvement (Furnham \& Bochner, 1986). These early studies described the U-curve of culture shock in terms of people's patterns of adjustment (Kauffmann \& Lysgaard, 1955). The three stages of culture shock 
were described as contact with the host culture. The predicted pattern suggests progression from the initial excitement and optimism about entering into a new culture to a downward shift in morale, which reflects cross-cultural differences and the accompanying negative affect. In the third stage of adaptation and recovery, there is a shift towards the top of the U-curve as coping strategies are mastered and morale increases. Oberg's W-shaped model was proposed as the expansion of the theoretical tenants of culture shock to include adaptation and adjustment when people return to their home culture (Gullahorn \& Gullahorn, 1963).

Adler (1975) proposed a five-stage model of the experience of culture shock that broadly follows the U-curve of sojourner adjustment but, in fact, resembles a W-curve. This model measures student morale versus their attitudes during their predeparture, time in culture, and reentry. His model not only considers travelers' emotions, perceptions, and behaviors, but also offers useful interpretations of those emotions and behaviors. During the initial contact state, the individual perceives differences between the host and the native culture to be intriguing and most perceptions are screened. The subject may experience excitement, euphoria, and a sense of discovery. During the second stage, differences have more impact, and disturbing contrasts between home and host cultures can no longer be ignored. The sojourner now experiences confusion, loss, apathy, and isolation and may appear withdrawn. According to Adler, this is due to intruding cultural differences and a growing awareness of being different, which leads to a loss of selfesteem. During the third stage, the individual experiences but does not understand cultural differences; common behaviors at this point may include stereotyping, generalizations, evaluation, and judgmental attitudes. Adler considers the exercise of 
each negative feeling to be a healthy sign of growing cultural awareness and an increasing ability to act on feelings. For Adler, this appears to be a critical stage during which individuals chose to regress to the superficial behaviors and responses of the contact phase. During the fourth stage, verbal and nonverbal skills improve and individuals are more relaxed. This stage is marked by increasing personal flexibility and the development of appropriate coping skills for the second culture. In the fifth and final stage, differences and similarities between cultures are valued, allowing the sojourner to experience trust, love, and humor with members of the host culture (Adler, 1975).

Recent conceptualization of culture shock (Pedersen, 1995; Ward, Bochner, \& Furnham, 2001; Winkleman, 1994) overcomes many of the criticisms levied against earlier models. Rather than viewing states of culture shock as discrete, they are considered to be sequential. The four primary phases of culture shock portray the general experience of cross-cultural transition: (a) the honeymoon phase, (b) the crisis or disintegration phase, (c) the gradual recovery phase, and (d) the adaptation or resolution phase (Pedersen, 1995; Winkelman, 1994). The processes within each phase account for the shifting nature of people's experiences in cross-cultural transition and that adaptation occurs through cultural adjustment gained through daily living experiences.

Although the focus of this dissertation is culture shock, it is important to note that when an event is very traumatic, a much more serious and longer lasting version of culture shock can occur. Known as posttraumatic stress disorder (PTSD), this, according to the National Institute of Mental Health and the Diagnostic and Statistic Manual of Mental Disorders $I V$, always follows a harrowing event which causes fear and/or helplessness in an individual. Examples of PTSD might include sexual abuse, harm by 
someone in the family, a victim of violent crime, or an event where you might have been killed. Typically, the duration of the symptoms develop shortly after the event and might take years to overcome. Culture shock characteristics, on the other hand, according to Oberg (1960), are short term and typically include the traits of loneliness, homesickness, social withdrawal, and excessive concerns for safety and health. The duration for culture shock might last from a week to 1 month. Fortunately, the responses of the students involved in this study gave no evidence of PTSD.

\section{Reentry Adjustments}

Even after adjusting to all the differences between home and host cultures, sojourners are not immune from further difficulties. Reentry shock occurs when a sojourner experiences some degree of alienation after returning to his or her original culture (Hess, 2002). Gullahorn and Gullahorn (1963) suggested that the shock of reentry appears as a second U-curve, such that the entire process of leaving the original culture and returning home resembles a $\mathrm{W}$-shaped curve when plotting emotional and cultural adjustment over time.

\section{Study Abroad Student Issues}

Research by Church (1982) suggests that although situational factors may influence sojourner adjustment, the relationships are not clear or consistent for all sojourner groups. For example, consistently higher morale has been reported for Peace Corps volunteers placed in rural locales than for those in urban assignments. However, foreign students may prefer universities in metropolitan areas with opportunities for extracurricular activities. 
Demographic factors also appear to impact sojourner adjustment. Research indicates that younger sojourners and undergraduate students generally have more social contact with host nationals, yet older sojourners and graduate students report more satisfaction with academic progress and the general sojourn experience (Church, 1982).

Language proficiency is closely related to the amount of social interaction with locals and is correlated to a lesser degree with general satisfaction and cultural adjustment (Ward \& Kennedy, 1993). Like language fluency, previous cross-cultural experience is generally thought to facilitate adjustment to other cultures (Marshall, 1989). However, some research suggests that the nature and quality (e.g., depth, intimacy, and similarity) of previous cross-cultural experiences may be more important than the number of exposures to new culture (Church, 1982).

Relatively few studies report gender differences regarding cultural adjustment. Some studies on foreign students suggest that female students report more adjustment problems than male students. Research with Claremont college students has found that female students seem to have more trouble than male students readjusting to life at college during the process of reentry (Novell, 1994).

\section{Ethnic Differences}

There is also the issue of ethnic differences. The NAFSA report of November 2003 indicates that the great majority of U.S. student sojourners travel mostly to western European nations. The typical study abroad traveler is likely to be Caucasian $(83 \%)$, of junior standing (41\%), and female (65\%); most have an experience lasting one semester (70\%) and come from a liberal arts background (95\%). It is interesting to note that a small percentage of ethnic minorities participate in these programs, while comprising 
$3.5 \%$ of the total student body of 2006 study abroad students (NAFSA, 2006). Mattau (1989) stated, however, that African Americans are better prepared to adjust to the rigors of culture change than their White classmates since African Americans have a long history of adjusting to White society, especially at the college/university level. He offered that financial challenges drive the success of African Americans who participate in study abroad.

Stress Issues

Previously, the process of sojourner adjustment has been described primarily as a struggle to adjust to a new physical and social stimulus. People who have experienced culture shock often describe a sense of confusion and disorientation in the foreign culture. Furthermore, research has shown that the numbers of individual and situational factors impact the adjustment process; in some cases, there may also be a significant individualsituation interaction (e.g., cultural fit). In essence, the study abroad experience may be considered a relatively ambiguous and complex stressor (Paige \& Martin, 1996).

In a rare longitudinal study, which traced the adjustment of 277 Canadian technical advisors assigned to 20 developing countries, Kealey (1989) found that only $10 \%$ of the individual data followed a U-curve trend when plotting satisfaction over six time periods. About $30 \%$ appeared to enter the new culture on a high (often referred to as the "honeymoon phase"). However, in contrast to the U-curve predictions, these sojourners did not experience a drop in satisfaction; rather, they continued to report levels of satisfaction that were higher than their predeparture levels.

Situation variables also impact the initial person-environment encounter and subsequent coping and mood. Sojourner research reviewed by Church (1982) indicates 
that the density of the sojourn's locale and the degree of difficulty with the new education system have a significant impact on students studying abroad. As Church noted, "Systematic assessment of psychological well-being is needed with individuals over time to vary curves of adjustment" (p. 561).

Evidence regarding the impact of the remaining situational variables is unclear. Briefly, students who experience little travel difficulty in reaching their study abroad destinations may be less fatigued and more likely to employ problem-solving coping strategies. Students who view their physical and social environments as favorable may be less likely to employ avoidant coping strategies. Those with predominantly host national friends (versus American or international friends) and those who live with a host family may have more resources for seeking social support and problem solving. Students whose ethnic background matches the predominant ethnic group in their host country may also have more resources for seeking social support and problem solving (Kohls, 2001).

The Michigan International Student Problem Inventory

The development of the Michigan International Student Problem Inventory (MISPI) originated with a study conducted by John Porter (1962). In 1961, 70,000 international students were enrolled in institutions of higher learning in the United States. There were some 700 international students enrolled at Michigan State University where Porter (1993) conducted his research. Porter (1993) was interested in comparing the problems of American university students with those of international students. To do so, he used two instruments to conduct the research. The Mooney Problem Checklist was the instrument used to gather data from American students. There were 47 American students involved in the study who completed this form. Porter (1993) surveyed a small group of 
international students with the instrument in order to compare the findings with the MISPI and establish the validity and consistency of the instrument. Porter (personal communication, April 21,2005) reported that over 200 doctoral students have used this survey instrument in the past 40 years.

\section{Summary}

Much of the literature in this area is long on theory and prescriptions, but is short on empirical work. For example, all scholars seem to agree that the Sputnik era of 1957 seemed to create awareness and a need for international understanding by the United States that was not obvious prior to this event. The events of September 11, 2001, also serve as a milestone in the internationalization of the United States with renewed concern about traveling overseas.

Readings also indicate that curriculum supporting language training and subjects of cultural awareness of the host country add to the success of the study abroad program (Paige, 1993). International scholars also agree that more direct faculty involvement in the training process adds to the success of the program.

The literature review also gives strong validation to those factors that create positive experiences leading to the internationalization of the student. These factors include such items as the host family, language capability, and the country visited. The readings indicate that the opportunities provided are extensive. Students gain independence, patience, maturity, and increased tolerance for different values and lifestyles, as well as a global perspective. These qualities, in turn, may make the students more attractive to potential employers after graduation. 
The readings also agree that people pursuing careers overseas usually have 2 years to adjust to the new environment while students studying abroad usually only have a matter of months during which to adapt to their new surroundings and achieve their goals. Students who cannot adjust under tight time limits are frequently left with doubts about their overseas experience. The literature also supports the fact that there are unique experiences that vary depending upon the culture of the country. Students who travel to cultures that are highly similar to the United States seem to experience some disorientation as they readjust to daily life in the United States (Paige, 1993). Early literature on the difficulties in adjustment experienced by sojourners suggested that sojourners often experienced confusion, frustration, and depression when transitioning between home and host cultures. The level of adjustment has been posited to vary over time according to the U- or W-curve (Gullahorn \& Gullahorn, 1963).

Unfortunately, evidence in support of such theories is relatively weak. Most previous research in this area has been cross-sectional rather than longitudinal. Comparing groups of students who have been in a country for varying lengths of time (e.g., 2 weeks, 6 weeks, and 12 weeks) is problematic unless the groups are matched on a number of key variables (e.g., age, language proficiency, knowledge about the host culture, etc.) that have been shown to impact adjustment abroad.

More recent research has suggested that the extent to which individuals experience culture shock may vary according to certain demographic variables (e.g., living conditions, task assignments, etc.). Unfortunately, the relative impact of such factors upon individual differences in culture adjustment is not well understood. 


\section{CHAPTER 3}

\section{METHODOLOGY}

The purpose of this study was to measure the reality of expectations of U.S. students who were studying abroad by comparing their predeparture hopes to the actual reality of that experience. This study also examined students' adjustment challenges upon return from their semester abroad program.

The Participants and the Programs

The population consisted of undergraduate students who had been accepted for semester abroad programs from a private university and a public university located in Southern California. All students who were accepted and intended to participate in the academic year 2005-2006 semester long study abroad programs were asked to participate in this study. With the cooperation of the directors of the study abroad programs, the researcher attended the first orientation meeting of the students at the private and public universities. During these meetings, the researcher introduced himself and the study to the students and described how to gain access to the web survey. The students were also advised of their confidentiality with the study. The students were also provided with written instructions and a consent form. A structured interview was also developed with general background observation to more specific or detailed experiences. There were approximately 300 students participating in the interview; 100 respondents were from the private university and 200 from the public university. Of that group, 114 students participated in both the predeparture and reentry surveys.

In the quantitative part of the study, a survey to measure the adaptations of U.S. students studying abroad was used (Appendix A). Permission was granted to use the 
modified version of the MISPI developed by John W. Porter, which he created in 1962 and modified in 1993 (Porter, 1993). Although this instrument was originally intended to measure the cultural adjustment of international students who were studying in the United States, the survey was adapted by this researcher to use with American university study abroad students. The use of this modified MISPI was granted by Dr. Porter, who has also willingly granted approval in the past (Appendices B and C).

Data were collected twice from students using the modified MISPI—once prior to their predeparture using the online "Survey Monkey" web survey to gather data on their expectations and then again upon their return to the United States to measure the actual levels of problems experienced. Although the original MISPI consisted of 11 problem areas with 12 specific questions in each area, the modified version only examined 9 of the problem areas since the original categories of Placement Services and Academic Advising and Records were deemed inappropriate for study abroad students. As such, the 9 problem areas studied were Student Admission-Selection, Social-Personal, Health Services, Student Activities, Living Dining, Religious Services, Host Language Capability, Orientation Services, and Financial Aid. At the end of the reentry survey, students' readjustment was measured with survey questions specifically designed to address their adjustment (Appendix D). A pilot of the survey was used for five veteran study abroad students to test the validity of the questions. The respondents in this pilot survey were selected from students who were known to the researcher.

\section{Procedure}

There were three phases to this study. The first phase occurred prior to the student departure for study abroad. The second phase was conducted upon their return and the 
third phase was the convening of a focus group for select participants to discuss important responses to the open-ended questions provided in the survey. Before launching into this study, the researcher met with the Director of Study Abroad at both the private and state universities to obtain permission and cooperation, as well as to discuss the details of the data collection. Procedural details were presented to the students during orientation in three sections (Phase 1, Phase 2, and Phase 3), with details particular to both participating universities where appropriate.

\section{Phase 1: Departure Questionnaire}

Students who were admitted into the study abroad program for academic year 2005-2006 were approached several months prior to their scheduled departure. With the cooperation of the directors of the study abroad programs, the researcher attended the first orientation meeting for the students at the private and public universities. During this meeting, the researcher introduced himself and the study to the students and explained how to gain access to the web survey. The students were also advised of the confidentiality of the study.

\section{Phase 2: Reentry Questionnaire}

Upon returning to the United States, students were notification by e-mail that the modified MISIP survey was posted on the web for their response. They were given a deadline of 1 month to accomplish the questionnaire. The researcher e-mailed those who did not immediately respond. Further, the researcher held a raffle for all participants for a gift certificate of $\$ 75.00$ from a local restaurant. 


\section{Phase 3: Focus Groups}

Each returning student from the private and public university programs was invited to participate in focus groups by indicating his or her interest on the final questionnaire. There was a focus group of 5 students from each school who were randomly selected from those who expressed interest in participating. Discussions were tape recorded and students were advised of their confidentiality with the study. A structured interview was developed that sought general background observations to more specific or detailed experiences. The focus group interview questions are provided in Appendix D.

Data Analysis

As noted above, this study used a modified version of the MISPI to measure student expectations for their study abroad experience and further measure the reality of that experience upon their return. The data collected from the surveys and interviews were analyzed as follows.

Survey Analysis

The respondent answers to the survey questions were entered into the statistical software program SPSS 12.0. Descriptive statistics were run for all demographic variables to determine the ranges, means, and significant differences for the sample. The variables included age, school, gender, and year in school, ethnicity, travel experience, and language capability.

\section{Summary of Analyses}

The next phase was to create an index that summarized the information contained with each of the nine categories (Appendix E). Specifically, respondents were asked to 
rate each question from 0 (no problem) to 3 (major problem). An average was calculated based on the 12 questions within each problem area with scores ranging from -3.00 to +3.00 . Since students completed the instrument twice, the difference between reality and expectation was simply calculated by subtracting the expected problem level from the actual problem level. For example, suppose that within the Social-Personal category problem area, the average response was 2.0 , but the average for actual problems was 1.0. The difference of +1 between the two measures would reflect the extent to which problems were underestimated (positive difference) or overestimated (negative difference). This information was presented for the entire sample, as well as by university, gender, and class level. To the extent possible, paired sample and independent sample $t$ tests were used for the significance of any observed differences between pre and post surveys, as well as among groups.

Analyses of the Focus Groups

The open-ended responses were categorized by recurring themes. These themes were the basis of the focus group conversations. These responses also addressed reentry adjustment challenges. Specifically, the researcher prepared an interview guide (Appendix D) and coded the initial categories. For example, one of the coding categories was "reentry adjustment" and discussed the types of activities the students recommend for an easier adjustment upon returning to the United States. 


\section{CHAPTER 4}

\section{DATA ANALYSIS}

\section{Introduction}

In this chapter, the data analysis of this study will be presented. Included will be a discussion of the survey population and sample, as well as the extent to which the demographics of the sample represent the study abroad population of the United States. This chapter will also respond to the research questions of the study, specifically, the adjustment problems study abroad students anticipate prior to their departure, the actual problems experienced during study abroad, the extent to which the students' expectations were actually realized, and the types of readjustment problems that were experienced upon their return.

\section{Demographics}

The target population for the study included all the students accepted into the study abroad programs for the academic school year of 2005-2006 at two Southern California universities-one private and one public. Since the number of applications accepted each year is limited, all students who were accepted and expressed their intention to participate in the semester abroad program for each school were invited to participate.

Although there were a number of students who completed only one of the two surveys (e.g., there were 199 students who completed the departure survey and 137 students who completed the reentry survey), there were 114 students who completed both and were the focus of this study. Of these students, 81 attended the public university and 33 attended the private school. As shown in Table 1, there were 18 males and 96 females, 
Table 1

Sample Demographics for the Study Abroad Participants

\begin{tabular}{|c|c|c|}
\hline Variable & Frequency & Percentage \\
\hline $\begin{array}{l}\text { Gender } \\
\text { Male } \\
\text { Female }\end{array}$ & $\begin{array}{l}18 \\
96\end{array}$ & $\begin{array}{l}15.8 \\
84.2\end{array}$ \\
\hline $\begin{array}{l}\text { Majors } \\
\text { Liberal Arts } \\
\text { Science } \\
\text { Business }\end{array}$ & $\begin{array}{l}75 \\
24 \\
15\end{array}$ & $\begin{array}{l}65.7 \\
21.1 \\
13.2\end{array}$ \\
\hline $\begin{array}{l}\text { Age } \\
19 \\
20 \\
21 \\
22 \\
23 \\
\text { Over } 24\end{array}$ & $\begin{array}{r}19 \\
64 \\
21 \\
3 \\
2 \\
5\end{array}$ & $\begin{array}{r}16.7 \\
56.1 \\
18.4 \\
2.6 \\
1.8 \\
4.4\end{array}$ \\
\hline $\begin{array}{l}\text { Ethnicity } \\
\text { Caucasian } \\
\text { Asian } \\
\text { Hispanic } \\
\text { European } \\
\text { African American } \\
\text { Middle Eastern } \\
\text { Pacific Islander }\end{array}$ & $\begin{array}{r}77 \\
23 \\
6 \\
5 \\
0 \\
1 \\
2 \\
\end{array}$ & $\begin{array}{r}67.5 \\
20.2 \\
5.3 \\
4.4 \\
0.0 \\
0.9 \\
1.8 \\
\end{array}$ \\
\hline $\begin{array}{l}\text { Communities } \\
\text { Rural } \\
\text { Urban } \\
\text { Suburban }\end{array}$ & $\begin{array}{l}36 \\
31 \\
47\end{array}$ & $\begin{array}{l}31.6 \\
27.2 \\
41.2\end{array}$ \\
\hline $\begin{array}{l}\text { Home State } \\
\text { Californian } \\
\text { Other U.S. States } \\
\text { Non-U.S. Citizen }\end{array}$ & $\begin{array}{r}88 \\
22 \\
4 \\
\end{array}$ & $\begin{array}{r}77.2 \\
19.3 \\
3.5 \\
\end{array}$ \\
\hline $\begin{array}{l}\text { Travel Experience } \\
\text { Previous } \\
\text { None }\end{array}$ & $\begin{array}{l}81 \\
33 \\
\end{array}$ & $\begin{array}{l}71.1 \\
28.9 \\
\end{array}$ \\
\hline
\end{tabular}

and these students ranged in age from 19 to 41 , with a mean age of 20.3. Slightly more that two thirds of the students identified themselves as Caucasian (67.5\%), 20.2\% as Asian or Asian American, $5.3 \%$ as Hispanic, $4.4 \%$ as European, and $1.8 \%$ as Pacific 
Islander. It is significant to note that there were no African Americans who participated in this study.

The participating students came from similar community backgrounds, with no significant differences between the private and public universities. For example, $41.2 \%$ reported that they came from a suburban setting, $31.6 \%$ stated that their homes were in rural areas, while $27.2 \%$ came from urban settings. Most of the students were from California (77\%), while 19.3\% reported living in other U.S. states. Four students were non-U.S. citizens $(3.5 \%)$.

Seventy-one percent of the students reported that they had previously experienced international travel, while $29 \%$ stated that this was their first experience. It is interesting to note that among those with international travel experience, $53 \%$ of that group had international travel experiences of 4 weeks or less, and most of this travel was to Mexico for weekend excursions (this is not surprising given the location of both universities).

The students participated in programs hosted by 25 countries around the globe: Australia, India, England, Spain, China, Japan, Scotland, Italy, Mexico, Barbados, Ireland, France, Brazil, Egypt, Singapore, Costa Rica, Chile, Ghana, Switzerland, Argentina, Portugal, Peru, Thailand, Northern Ireland, and the Semester-at-Sea program. Among participants, 21\% studied in Spain; 16\% studied in England; 10\% studied in Italy; $14 \%$ studied in other European countries; $12 \%$ traveled to the Pacific Rim; $15 \%$ studied in Latin America; and less than 12\% sojourned to the Mediterranean, Eastern Europe, the Caribbean, and North America.

Most importantly, two thirds (67\%) of the students went to countries where English was not a primary language. It is also important to note that the great majority of 
the students were native English speakers (86\%) with all other native languages rated $2 \%$ or less. These languages include Korean (0.9\%), Spanish (1.8\%), Arabic (2.8\%), Mandarin (1.8\%), Cantonese $(0.9 \%)$ and Japanese $(0.9 \%)$. There were no significant differences in native language capabilities between the private and public universities. With respect to housing, the surveys reflected that $43 \%$ of the students primarily resided in dormitories, while $37 \%$ lived with host families and $21 \%$ lived in their own private accommodation in the host country (hotel, rented apartments, etc.). There were no significant differences between the public and private universities in the area of housing. The complete listing of demographic frequencies is found in Appendix F.

The Private University

The private religiously-affiliated university, located in a large Southern California city, is a doctoral comprehensive university with approximately 7,200 students. During the 2005-2006 academic year, there were 120 study abroad undergraduates; their declared majors were Psychology (10\%), International Relations (10\%), Political Science (14\%), Communications (10\%), Languages (10\%), Business Administration (16\%), History (5\%) and assorted other majors that included Engineering, Literature, Computer Science, and Mathematics.

At this institution, the study abroad program actually consists of three separate programs, each with its own organizational structure and method of recruiting. These programs are managed individually through the School Leadership and Education Sciences, School of Business Administration, and the College of Arts and Sciences; however, the majority of study abroad students participate through Arts and Sciences. 
Although there were 30 females who completed both the departure and reentry surveys from this university, unfortunately there were only 3 males. The majority of these students (67.7\%) were liberal arts majors, while $27 \%$ were business students and $5.4 \%$ majored in science-related curriculum.

As shown in Table 2, these students ranged from 19 years old (18.2\%) to over 24 years old (3\%); however, almost two thirds of these students were 20 years of age. The ethnicity of the private school students was mostly Caucasian (75.8\%), followed by Asian (9.1\%), Hispanic (6.1\%), Middle Eastern (3\%), and Pacific Islander (3\%). In addition, $43 \%$ of these students were from suburban areas, $30 \%$ from rural, and $26 \%$ from urban areas of the city. Most of the students were Californians (52\%), with $45 \%$ from other U.S. states, and $3 \%$ were non-U.S. citizens.

Regarding previous international travel, $70 \%$ of the private university students indicated that they had previous travel experience, while $30 \%$ had no previous experiences. The results of the survey also indicated that the majority of the private school students had spent an average of 4 weeks out of the country, and focus group discussions provided evidence that the majority of those visits were within 50 miles of the U.S. and Mexican border.

\section{The Public University}

The public university is also located in Southern California and is a researchbased doctoral university. This state school has an enrollment of approximately 25,000 students, including 800 study abroad students enrolled in a wide range of majors including Bioengineering, Chemistry, Computer Engineering, Computer Science, Biology, Psychology and Management Science, Liberal Studies, Languages, and Political 
Table 2

Demographics by School Type $(N=114)$

\begin{tabular}{|c|c|c|c|c|}
\hline \multirow[t]{2}{*}{ Variable } & \multicolumn{2}{|c|}{ Private } & \multicolumn{2}{|c|}{ Public } \\
\hline & Frequency & Percentage & Frequency & Percentage \\
\hline $\begin{array}{l}\text { Gender } \\
\text { Males } \\
\text { Females }\end{array}$ & $\begin{array}{r}3 \\
30\end{array}$ & $\begin{array}{r}9.1 \\
90.9\end{array}$ & $\begin{array}{l}15 \\
66\end{array}$ & $\begin{array}{l}18.5 \\
81.5\end{array}$ \\
\hline $\begin{array}{l}\text { Majors } \\
\text { Liberal Arts } \\
\text { Science } \\
\text { Business }\end{array}$ & $\begin{array}{r}25 \\
2 \\
10\end{array}$ & $\begin{array}{r}67.5 \\
5.4 \\
27.1\end{array}$ & $\begin{array}{c}50 \\
22 \\
5\end{array}$ & $\begin{array}{r}64.9 \\
28.6 \\
6.5\end{array}$ \\
\hline $\begin{array}{l}\text { Age } \\
19 \\
20 \\
21 \\
22 \\
23 \\
\text { Over } 24\end{array}$ & $\begin{array}{r}6 \\
22 \\
1 \\
1 \\
2 \\
1\end{array}$ & $\begin{array}{r}18.2 \\
66.7 \\
3.0 \\
3.0 \\
6.1 \\
3.0\end{array}$ & $\begin{array}{r}14 \\
42 \\
20 \\
2 \\
0 \\
3\end{array}$ & $\begin{array}{r}17.3 \\
51.9 \\
24.7 \\
2.5 \\
0.0 \\
3.6\end{array}$ \\
\hline $\begin{array}{l}\text { Ethnicity } \\
\text { Caucasian } \\
\text { Asian } \\
\text { Hispanic } \\
\text { European } \\
\text { African American } \\
\text { Middle Eastern } \\
\text { Pacific Islander }\end{array}$ & $\begin{array}{r}25 \\
3 \\
2 \\
1 \\
0 \\
1 \\
1\end{array}$ & $\begin{array}{r}75.8 \\
9.1 \\
6.1 \\
0.0 \\
0.0 \\
3.0 \\
3.0 \\
\end{array}$ & $\begin{array}{r}52 \\
20 \\
5 \\
3 \\
0 \\
0 \\
1 \\
\end{array}$ & $\begin{array}{r}64.2 \\
24.7 \\
6.2 \\
3.7 \\
0.0 \\
0.0 \\
1.2 \\
\end{array}$ \\
\hline $\begin{array}{l}\text { Communities } \\
\text { Rural } \\
\text { Urban } \\
\text { Suburban }\end{array}$ & $\begin{array}{l}11 \\
10 \\
12\end{array}$ & $\begin{array}{l}33.3 \\
30.3 \\
36.4\end{array}$ & $\begin{array}{l}25 \\
21 \\
35\end{array}$ & $\begin{array}{l}30.9 \\
25.9 \\
43.3\end{array}$ \\
\hline $\begin{array}{l}\text { Home State } \\
\text { Californian } \\
\text { Other U.S. States } \\
\text { Non-U.S. Citizens }\end{array}$ & $\begin{array}{r}17 \\
15 \\
1\end{array}$ & $\begin{array}{r}51.5 \\
45.5 \\
3.0\end{array}$ & $\begin{array}{r}71 \\
7 \\
3\end{array}$ & $\begin{array}{r}87.7 \\
9.7 \\
2.0\end{array}$ \\
\hline $\begin{array}{l}\text { Travel Experience } \\
\text { Previous } \\
\text { None }\end{array}$ & $\begin{array}{l}23 \\
10\end{array}$ & $\begin{array}{l}69.7 \\
30.3\end{array}$ & $\begin{array}{l}58 \\
23\end{array}$ & $\begin{array}{l}71.6 \\
28.4\end{array}$ \\
\hline
\end{tabular}


Science. The international study abroad program is centrally managed by the university though the Education Abroad Program (EAP).

As shown in Table 2, there were 15 males $(18 \%)$ and 66 females $(82 \%)$ from the public university who responded to both the departure and reentry surveys for a total of 81 respondents. The majority of these students were liberal arts majors (65\%), while $29 \%$ of them were science majors and $7 \%$ were business majors. Similar to the private school, the majority of the students were 20 years old (52\%), followed in descending order by 21-year-olds (25\%) and 19-year-olds (17\%). The most common ethnicity for the public school was Caucasian at $64.2 \%$, followed by Asian at $24.7 \%$, Hispanic at $6.2 \%$, European at $3.7 \%$, and Pacific Islander at $1.2 \%$. There were more public school students who came from suburban settings (43\%) as compared to the private school $(36 \%)$, with $31 \%$ of the participating public school students coming from rural areas and $26 \%$ from urban townships. However, the public school and the private school students had similar experiences with previous international travel; for example, $72 \%$ of public school students reported previous international travel, while $28 \%$ did not. For a complete demographic profile of students, please see Appendix F.

Data Analysis

The primary purpose of this study was to investigate the perceptions and expectations of the international study abroad students from two universities located in Southern California. To that extent, in this section the results of the data analysis are presented research question by research question, beginning with the following:

Research Question 1: What kinds of adjustment problems do study abroad students anticipate prior to their departure for study abroad? 
As shown in Table 3, the 114 respondents who completed both the departure and reentry surveys reported that their number one concern was Financial Aid, with a mean score of 10.32 on a 36 -point scale; since this score was calculated as the sum of students' responses to 12 individual questions, the score of 10.32 , which reflects an average response of slightly less than "1" per question, shows that even the most highly anticipated problem by students - in this case Financial Aid — was technically only a "minor" problem. Although there was greater concern amongst the private school students (11.42) than amongst those of the public university (9.23), these differences were not statistically significant at the $p=.05$ level.

\section{Table 3}

Mean Score (in Descending Order) for Nine Potential Problem Areas by University

\begin{tabular}{|c|l|c|c|c|}
\hline Ranking & Category & Overall & Private & Public \\
\hline 1 & Financial Aid & 10.32 & 11.42 & 9.23 \\
\hline 2 & Social-Personal & 9.42 & 10.09 & 8.76 \\
\hline 3 & Host Language & 8.87 & 10.18 & 7.38 \\
\hline 4 & Student Admission/Selection & 8.84 & 9.81 & 7.86 \\
\hline 5 & Orientation Services & 8.36 & 9.48 & 7.25 \\
\hline 6 & Living and Dining & 7.73 & 9.27 & 6.19 \\
\hline 7 & Health and Safety & 7.31 & 8.51 & 6.12 \\
\hline 8 & Student Activities & 5.54 & 6.48 & 5.41 \\
\hline 9 & Religious Services & 4.69 & 5.69 & 3.70 \\
\hline
\end{tabular}

Note. $t$ tests indicated that significant differences existed between the private and public universities in the areas of Living and Dining, Orientation Services, and Health and Safety at the $p=.05$ level.

When the 12 individual statements that made up the Financial Aid category were examined separately, the major areas of financial concerns (as expressed by their average scores on a 0 - to 3-point scale) were "the lack of money for travel" (1.53), "the anticipation of unexpected financial needs" (1.14), and "the concern for the limited 
buying power of the dollar" (1.09). Additionally, there were significant differences between the two schools in the areas of the "buying power of the dollar," with the private school showing a greater concern (1.44) than the public school (0.88), as well as "money for clothing," where students at the public school expressed more concern than did those at the private school (0.94 vs. 0.55$)$.

The second major category of concern for the students during predeparture was the area of Social-Personal, with a collective mean of 9.42, again classified only as a minor problem. Within this area, as shown in Table 4, the major concerns for students were "homesickness" (1.23); "worry of being lonely" (1.13); and "nervousness," with a mean of 0.93 . The only significant difference between students at the two schools was their concern about being a "student ambassador," where private school students expressed more concern than public school students ( 0.89 vs. 0.53$)$.

The third ranking predeparture concern was the Host Language issue, with an overall average score of 8.87 . The collective major concerns for this category were "speaking the host nation language" (0.95) and "the ability to read the host nation language" $(0.96)$; the only area where there were significant differences between the two groups of students was in "understanding lectures," where those from the public school expressed more concern than those from the private school $(0.97$ vs. 0.36$)$ at the $p=.05$ level.

The fourth ranking category was Student Admission/Selection, which had an overall mean score of 8.84 . Within this category, the number one issue for students prior to their departure was "concern for GPA" (1.18), followed by "concern over being a 
Table 4

Top Concerns Predeparture Within Each Category

\begin{tabular}{|c|c|c|c|}
\hline Category & Rank & Concern & Mean \\
\hline \multirow[t]{3}{*}{ Financial Aid } & 1 & Lack of money for travel & 1.53 \\
\hline & 2 & Unexpected financial needs & 1.14 \\
\hline & 3 & Limited buying power of U.S. dollar & 1.09 \\
\hline \multirow[t]{3}{*}{ Health and Safety } & 1 & Concern about being a foreign student & 1.10 \\
\hline & 2 & Feeling under tension/stress & 0.88 \\
\hline & 3 & Need more time to rest & 0.64 \\
\hline \multirow[t]{3}{*}{ Orientation Services } & 1 & $\begin{array}{l}\text { Treatment received during my arrival } \\
\text { orientation meeting }\end{array}$ & 0.99 \\
\hline & 2 & $\begin{array}{l}\text { Registration for classes at home } \\
\text { university }\end{array}$ & 0.85 \\
\hline & 3 & Being accepted in social groups & 0.84 \\
\hline \multirow{3}{*}{$\begin{array}{l}\text { Student } \\
\text { Admission/Selection }\end{array}$} & 1 & Concerned about my GPA & 1.18 \\
\hline & 2 & Concern about being a foreign student & 1.10 \\
\hline & 3 & Writing term papers & 1.05 \\
\hline \multirow[t]{3}{*}{ Social-Personal } & 1 & Homesickness & 1.23 \\
\hline & 2 & Being lonely & 1.13 \\
\hline & 3 & Nervousness & 0.93 \\
\hline \multirow[t]{3}{*}{ Host Language } & 1 & Speaking host country language & 0.96 \\
\hline & 2 & Understanding host country language & 0.95 \\
\hline & 3 & Ability to read host country language & 0.85 \\
\hline \multirow[t]{3}{*}{ Living and Dining } & 1 & Not being able to find my way & 1.04 \\
\hline & 2 & Problems regarding housing & 0.88 \\
\hline & 3 & Relationship with roommates & 0.84 \\
\hline \multirow[t]{3}{*}{ Religious Services } & 1 & $\begin{array}{l}\text { Lack of knowledge about host } \\
\text { country }\end{array}$ & 0.92 \\
\hline & 2 & $\begin{array}{l}\text { Study abroad spirituality was not } \\
\text { what was expected }\end{array}$ & 0.58 \\
\hline & 3 & $\begin{array}{l}\text { Confusion about American and host } \\
\text { country morals }\end{array}$ & 0.50 \\
\hline \multirow[t]{3}{*}{ Student Activities } & 1 & Trying to make friends & 0.88 \\
\hline & 2 & $\begin{array}{l}\text { Attitude of some against American } \\
\text { students }\end{array}$ & 0.85 \\
\hline & 3 & $\begin{array}{l}\text { Opportunities to meet more host } \\
\text { nation people }\end{array}$ & 0.68 \\
\hline
\end{tabular}


foreign student" (1.10) and "concern about writing term papers" (1.05). There were no significant differences between the two schools in this category.

The fifth category of concern for the predeparture study abroad students was Orientation Services, with an overall mean of 8.36 . For this category, there were significant differences in the overall mean scores between public university (7.25) and private university students $(9.48)$, with the private university students expressing more concern. In addition, there was also a significant difference in the specific statement that involves a "feeling of superiority while in the host country," where private school students expressed more concern than their public university counterparts $(0.18$ vs. 0.06$)$. The highest ranking concerns within this category were "concern about their treatment upon arrival into the host country" (0.99, "registration for classes upon returning home $(0.85)$ and "being accepted in social groups in the host country" $(0.84)$.

The next area of concern was that of Living and Dining, with a mean score of 7.73; again, the difference between private and public university students was significant, with the private school students expressing more concern (9.27 vs. 6.19). The major concerns were "not being able to find my way" (1.04), "problems regarding student housing" (0.88), and "relationships with roommates" $(0.84)$. Significant differences between the private and the public universities were found in the "taste of food" ( 0.77 vs. 0.44), "types and comfort of accommodations" (0.86 vs. 0.36$)$, "daily traveled distances to school" $(0.89$ vs. 0.29$)$, and "the perceived lack of appropriate housing," with a mean score of 0.00 for public school students as compared with 0.38 for the public university students. 
The seventh category of concern was the area of Health and Safety (7.31), where a significant difference existed between the public and private university school students (8.51 vs. 6.12). The greatest areas of student concern were "about being a foreign student in the host country" (1.10), "feeling of stress" $(0.88)$, and "no time for rest" $(0.64)$. In the area of "host nation politics," significant differences existed between the private and the public schools ( 0.92 vs. 0.42$)$, as well as in the areas of "insufficient rest" (0.94 vs. 0.39) and concern about "political discussions in the host country" ( 0.97 vs. 0.49$)$.

The eighth category was the area of Student Activities, with a mean score of 5.54. Importantly, this value-which reflects an average score per question closer to 0 than 1 -suggests that the area of Student Activities was considered to be "no problem" by predeparture students. Within this category, the major concern for the students was their "ability to meet host nation families" ( 0.83$)$, followed by "making new friends" $(0.66)$ and "worry over the attitude that host nation people might have against Americans in general" $(0.54)$. There were no significant differences between the students of the two schools in their predeparture expectations.

The least problematic category for departing students was that of Religious Activities, with a collective mean of 4.69. The major concern for the students within this area was a "lack of knowledge of the faith and spirituality of their host country" $(0.92)$, followed by the "worry that the study abroad spirituality opportunities would not be what was expected" ( 0.58$)$ and "confusion over host country morality issues" $(0.50)$. There was also one area where significant differences existed between the two groups of university students: "finding opportunities for religious experiences," where private 
school students expressed more concern than their public school counterparts $(0.64$ vs. 0.17).

In summary, there were no major or even moderate concerns for students predeparture. In fact, in seven of the nine potential problem areas, students rated their anticipated problems as "minor," while the other two areas were rated as "no problem." Specifically, the area of greatest concern was for Financial Aid, with a mean of 10.36 out of a possible score of 36.0 ; however, even this problem was considered minor on that scale of potential problems. As shown in Table 5, within those areas of concern the "lack of money for travel," "homesickness," "concern for GPA," "unexpected financial needs," "being lonely," "concern about being a foreign student," "the limited buying power of the dollar," "writing in a foreign language," "getting lost," and "worries over arrival orientation" were listed as the top 10 adjustment issues expected by the students.

Table 5

Major Concerns Reported Predeparture (in Descending Order)

\begin{tabular}{|c|l|l|}
\hline Ranking & \multicolumn{1}{|c|}{ Expectation } & \multicolumn{1}{|c|}{ Category } \\
\hline 1 & Lack of money for travel & Financial Aid \\
\hline 2 & Homesickness & Social-Personal \\
\hline 3 & Concerned about my GPA & Student Admission \\
\hline 4 & Unexpected financial needs & Financial Aid \\
\hline 5 & Being lonely & Social-Personal \\
\hline 6 & Concern about being a foreign student & Health and Safety \\
\hline 7 & Limited buying power of U.S. dollar & Financial Aid \\
\hline 8 & Writing term papers & Admission/Selection \\
\hline 9 & Not being able to find my way & Living and Dining \\
\hline 10 & Treatment received during arrival orientation meeting & Orientation Services \\
\hline 11 & Speaking host country language & Host Language \\
\hline 12 & Understanding host language & Host Language \\
\hline 13 & Nervousness & Social-Personal \\
\hline 14 & Lack of knowledge about host country & Religious Services \\
\hline 15 & Feeling under tension/stress & Health and Safety \\
\hline
\end{tabular}


Table 6 demonstrates the significant differences between the two universities without respect to the individual items. These differences are provided to illustrate the dissimilarities of concerns between the private and public university students reported at predeparture. For example, the private school students were much more concerned about sufficient study time, their reading comprehension, and the buying power of the dollar when compared to those from the public university. On the other hand, the public university students viewed the ability to understand lectures and a sense of superiority as a greater significance than their counterparts at the private school.

Table 6

Significant Differences in Variables Between Private and Public University Study Abroad Students Predeparture

\begin{tabular}{|l|c|c|c|}
\hline Variable & $\begin{array}{c}\text { Private School } \\
\text { Mean }\end{array}$ & $\begin{array}{c}\text { Public School } \\
\text { Mean }\end{array}$ & $\begin{array}{c}\text { Level of } \\
\text { Statistical } \\
\text { Significance }\end{array}$ \\
\hline Taste of Food & 0.77 & 0.44 & .04 \\
\hline Accommodations & 0.86 & 0.36 & .00 \\
\hline Feeling of Superiority & 0.06 & 0.18 & .00 \\
\hline Lack of Study Time & 1.36 & 0.65 & .00 \\
\hline Study Abroad Advisors & 0.56 & 0.31 & .01 \\
\hline Having U.S. Roommate & 0.64 & 0.27 & .03 \\
\hline Understanding Lectures & 0.36 & 0.97 & .00 \\
\hline Reading Comprehension & 1.22 & 0.68 & .00 \\
\hline Buying Power of Dollar & 1.44 & 0.88 & .02 \\
\hline Host Country Politics & 0.92 & 0.42 & .00 \\
\hline Distances to School & 0.89 & 0.29 & .01 \\
\hline Insufficient Rest & 0.94 & 0.39 & .05 \\
\hline Religious activities & 0.64 & 0.17 & .00 \\
\hline Money for Clothing & 0.94 & 0.55 & .05 \\
\hline Student Ambassador & 0.89 & 0.54 & .01 \\
\hline Appropriate Housing & 0.00 & 0.38 & .00 \\
\hline Political Discussions & 0.97 & 0.49 & .00 \\
\hline
\end{tabular}


A Final Issue Regarding Sample Size

In addition to the 114 students that took both the predeparture and reentry surveys, there were an additional 85 students that took only the predeparture survey. To ensure that these 85 students were not systematically different from those who responded to both surveys in terms of their ex-tests expected problem levels, independent sample $t$ tests were used to test for differences between these two groups of students in all nine problem areas (Living and Dining, Student Admissions/Selections, Orientation Services, Financial Aid, Health and Safety, Religious Services, Host Language, Social-Personal, and Student Activities). The results of this series of tests revealed that there were no significant differences in the level of expected problems between these groups of students, suggesting that attrition among respondents was unlikely to have introduced any bias into the final results.

\section{Research Question 2: What are the problems experienced during the study} abroad experience?

As expected, the actual problems experienced during the study abroad experience differed from student expectations; however, what was surprising is how little they actually differed. For example, as shown in Table 7, the top reentry concerns were (in descending order): Social-Personal, Financial Aid, Orientation Services, Host Language, Living and Dining, Health and Safety, Student Activities, Religious Services, and Student Admission/Selection, and the low overall averages suggest that few, if any, problems were experienced. For the purposes of this study, the term "reentry" is used to describe the survey responses of those students who have just completed their sojourn abroad. 
Table 7

Mean Rankings of Categories Upon Reentry (in Descending Order)

\begin{tabular}{|c|l|c|c|c|}
\hline Ranking & Category & Private & Public & Overall \\
\hline 1 & Social-Personal & 7.03 & 7.05 & 7.04 \\
\hline 2 & Financial Aid & 6.69 & 6.64 & 6.66 \\
\hline 3 & Orientation Services & 6.09 & 5.73 & 5.91 \\
\hline 4 & Host Language & 5.08 & 6.34 & 5.71 \\
\hline 5 & Living and Dining & 5.64 & 5.64 & 5.64 \\
\hline 6 & Health and Safety & 4.94 & 4.45 & 4.69 \\
\hline 7 & Student Activities & 4.67 & 4.64 & 4.65 \\
\hline 8 & Religious Services & 3.76 & 2.86 & 3.31 \\
\hline 9 & Student Admission/Selection & 3.45 & 1.29 & 2.37 \\
\hline
\end{tabular}

Note: $t$ tests indicated no significant differences existed between the two schools in any of the categories.

As shown in Table 7, the Social-Personal category was ranked as the top concern, with a mean score of 7.04 on a 36-point scale, although technically this area was only a "minor" problem. Within this category, as shown in Table 8, the top reentry concern was in the area of "homesickness" $(0.94)$, followed by the sense of "being lonely" $(0.92)$ and "trying to meet new friends" (0.80). Additionally, there were three specific areas"personal social life," "social treatment," and "the ability to meet new friends"-where the private school students experienced significantly fewer problems than the public school students ( 0.25 vs. $0.47,0.28$ vs. 0.61 , and 0.44 . vs. 0.90 , respectively).

The second major problem area at reentry was that of Financial Aid (6.66). Specifically, the students considered their "lack of money for travel" as their most problematic issue, with a mean score of 1.07. This was followed by the "limited buying power of the dollar" $(0.96)$ and "having enough money for social events" (0.75). As shown in Table 9, $t$ tests indicated that there was a significant difference in responses to the limited buying power of the dollar issue, with private school students experiencing 
Table 8

Top Concerns Upon Reentry According to Category

\begin{tabular}{|c|c|c|c|}
\hline Category & Rank & Expectation & Mean \\
\hline \multirow{3}{*}{ Financial Aid } & 1 & Lack of money for travel & 1.07 \\
\hline & 2 & Limited buying power of U.S. dollar & 0.96 \\
\hline & 3 & Having enough money for social events & 0.75 \\
\hline \multirow[t]{3}{*}{ Health and Safety } & 1 & Concern about being a foreign student & 0.97 \\
\hline & 2 & Feeling under tension/stress & 0.50 \\
\hline & 3 & Finding adequate health services & 0.47 \\
\hline \multirow[t]{3}{*}{ Orientation Services } & 1 & $\begin{array}{l}\text { Registration for classes at home } \\
\text { university }\end{array}$ & 0.81 \\
\hline & 2 & $\begin{array}{l}\text { Activities of fellow Americans in host } \\
\text { country }\end{array}$ & 0.60 \\
\hline & 3 & Being accepted in social groups & 0.59 \\
\hline \multirow{3}{*}{$\begin{array}{l}\text { Student } \\
\text { Admission/Selection }\end{array}$} & 1 & Concern about my GPA & 1.24 \\
\hline & 2 & Concern about being a foreign student & 0.97 \\
\hline & 3 & Writing term papers & 0.77 \\
\hline \multirow[t]{3}{*}{ Social-Personal } & 1 & Homesickness & 0.94 \\
\hline & 2 & Being lonely & 0.92 \\
\hline & 3 & Trying to make new friends & 0.80 \\
\hline \multirow[t]{3}{*}{ Host Language } & 1 & Speaking host country language & 0.96 \\
\hline & 2 & Ability to read host country language & 0.81 \\
\hline & 3 & Hard to understand foreign tongue & 0.76 \\
\hline \multirow[t]{3}{*}{ Living and Dining } & 1 & Problems regarding housing & 0.83 \\
\hline & 2 & Not being able to find my way & 0.63 \\
\hline & 3 & Taste of food in host country & 0.61 \\
\hline \multirow[t]{3}{*}{ Religious Services } & 1 & Lack of knowledge about host country & 0.51 \\
\hline & 2 & $\begin{array}{l}\text { Study abroad spirituality was not what } \\
\text { was expected }\end{array}$ & 0.46 \\
\hline & 3 & Insufficient personal-social counseling & 0.43 \\
\hline \multirow[t]{3}{*}{ Student Activities } & 1 & $\begin{array}{l}\text { Opportunities to meet more host nation } \\
\text { people }\end{array}$ & 0.76 \\
\hline & 2 & Trying to make friends & 0.66 \\
\hline & 3 & $\begin{array}{l}\text { Attitude of some against American } \\
\text { students }\end{array}$ & 0.54 \\
\hline
\end{tabular}


Table 9

Significant Differences in Variables Between Private and Public University Study Abroad Students Upon Reentry

\begin{tabular}{|l|c|c|c|}
\hline \multicolumn{1}{|c|}{ Variable } & $\begin{array}{c}\text { Private School } \\
\text { Mean }\end{array}$ & $\begin{array}{c}\text { Public School } \\
\text { Mean }\end{array}$ & $\begin{array}{c}\text { Level of } \\
\text { Statistical } \\
\text { Significance }\end{array}$ \\
\hline Personal Social Life & 0.25 & 0.47 & .00 \\
\hline Social Treatment & 0.28 & 0.61 & .00 \\
\hline Making New Friends & 0.44 & 0.90 & .00 \\
\hline Social Invitations & 0.22 & 0.67 & .00 \\
\hline Buying Power of Dollar & 1.28 & 0.73 & .01 \\
\hline Insufficient Rest & 0.72 & 0.22 & .00 \\
\hline Presentations & 0.08 & 0.23 & .04 \\
\hline Mental Stress & 0.58 & 0.25 & .05 \\
\hline
\end{tabular}

considerably more problems than their counterparts (1.28 vs. 0.78$)$. This technically would also be considered a "minor problem."

It is also significant to note that the first two categories in the reentry survey-Social-Personal and Financial Aid - were considered only "minor" problems because their mean scores were between 6 and 18, reflecting an average score per question in the minor range. As such, an overall average of less than 6 points would be considered "no problem," as is the case with the next seven categories - Orientation Services (5.91), Host Language (5.71), Living and Dining (5.64), Health and Safety (4.69), Student Activities (4.65), Religious Services (3.31), and Student

\section{Admission/Selection (2.37).}

With this classification in mind, the third ranked problem category was Orientation Services. The first concern was the "challenge of registering for classes for the next semester at the home university" $(0.81)$, while the second concern was "the conduct of fellow Americans in the host country" $(0.60)$. In the view of the focus study 
students, there should have been better briefings on culture and what might be considered unacceptable behavior in the host country during orientation. The third most important worry was "not being accepted into certain social groups" $(0.59)$. This, too, was related to orientation briefings and the lack of general awareness that certain countries do not readily accept foreigners into private clubs, or some social circles.

The fourth most problematic area of concern was that of the Host Language, where the top problems in this area centered on the host country language comprehension (5.71). Specifically, the first was the "challenge of speaking the host nation language comfortably" $(0.96)$, followed by "speaking the host nation language" $(0.96)$ and "the ability to read host country language" $(0.81)$. The only significant difference that existed in this category was that of "the ability to make classroom presentations," which was more worrisome to the public university student $(0.23$ vs. 0.08$)$ than to the private students.

The fifth area of concern for the returning students was Living and Dining. The first problem regarded student housing $(0.83)$, which varied with the location, as some housing was clearly better than others. Another major issue in this area was the student frustration of not being able to find their way around during travels $(0.63)$, while the third issue was the taste of host nation food (0.61). There were no significant differences here between the students from the two schools.

The sixth ranked category for reentry problems was that of Health and Safety. The major issue here was "the concern about being a foreign student" $(0.97)$, followed by "feelings of stress and tension" $(0.50)$ and "finding adequate health services" $(0.97)$. 
There was one significant difference between the schools in the area of mental stress, with a mean of 0.58 for the private school and 0.25 for the public university.

The seventh problem area was Student Activities. The three major concerns were "the host nation attitude against American students" (0.80), "limited opportunities to meet host nation people" $(0.43)$, and "trying to meet new friends" $(0.23)$. In this category, there were significant differences between the private and public university students; specifically, the private school students found that their personal social life was not as stressful as the public school students $(0.25$ vs. 0.47$)$. Also significant between the private and the public schools was "the ability to make new friends within the host nation" (0.44 vs. 0.90$)$. A final significant issue was the subject of social invitations to various events, which was more of a problem for the private school $(0.44)$ than for the public school (0.90).

The eighth category was Religious Services, with a mean score of 3.31 . In this area, the biggest problem was the "lack of knowledge about host country religion and religious practices" $(0.51)$, followed by the issue that "study abroad spirituality was not what was expected" $(0.46)$ and that there was "insufficient personal-social counseling in the area of host country morality and standards" $(0.54)$.

The final and least problematic category upon reentry was Student Admission/Selection, with an overall mean score of 2.37 . The major problem for students in this area was "the affect study abroad had on their GPA" (1.24). This issue was discussed at length with the focus group and, in the opinion of both private and public school students, their GPAs suffered due to the stricter grading requirements of the study abroad instructors. Focus group discussion also highlighted the concern about registering 
for study abroad elective classes outside of their majors. There were also worries about their foreign student status in the host country $(0.97)$ and their ability to write term papers versus the abilities of the other students $(0.77)$. Within this area, there were no differences between the two groups of participating students.

In summary, the problems faced by students during their study abroad experienced are found in Table 10. The top 10 listings in descending order were concern for GPA, lack of money for travel, concern about being a foreign student, limited buying power of the dollar, speaking the host country language, homesickness, being lonely, problems regarding housing, and the ability to read in the host language. Based on the categorical mean scores, there were no major or even moderate problems noted on reentry.

Table 10

Major Expectations Upon Reentry (in Descending Order)

\begin{tabular}{|c|l|l|}
\hline Ranking & \multicolumn{1}{|c|}{ Expectations } & \multicolumn{1}{c|}{ Category } \\
\hline 1 & Concern about my GPA & Student Admission/Selection \\
\hline 2 & Lack of money for travel & Financial Aid \\
\hline 3 & Concern about being a foreign student & Health and Safety \\
\hline 4 & Limited buying power of U.S. dollar & Financial Aid \\
\hline 5 & Speaking host country language & Host Language \\
\hline 6 & Homesickness & Social-Personal \\
\hline 7 & Being lonely & Social-Personal \\
\hline 8 & Problems regarding housing & Living and Dining \\
\hline 9 & Registration for classes at home university & Orientation Services \\
\hline 10 & Ability to read host language & Host Language \\
\hline 11 & Trying to make new friends & Social-Personal \\
\hline 12 & Writing term papers & Student Admission/Selection \\
\hline 13 & Hard to understand foreign tongue & Host Language \\
\hline 14 & $\begin{array}{l}\text { Opportunities to meet more host nation } \\
\text { people }\end{array}$ & Student Activities \\
\hline 15 & Having enough money for social events & Financial Aid \\
\hline & & \\
\hline
\end{tabular}




\section{Research Question 3: To what extent are the student's expectations regarding}

\section{problems truly realized?}

The first two research questions in this dissertation gathered information from students regarding both the types and magnitude of problems expected during their study abroad experience, as well as the actual problems encountered; this information is combined in this section to produce a measure of how well students anticipated the actual problems that occurred. This was accomplished by numerically subtracting the mean level of problems expected from those that actually occurred; as such, a negative value for any category suggests that the level of anticipated problems exceeded the problems actually experienced. Similarly, a positive value shows that the actual problems experienced by students were greater than those anticipated.

This information is presented in Table 11 , and the fact that the mean change in all nine problem categories is negative shows that the actual problems experienced by the students were consistently less than what they expected; moreover, in all nine problem areas these differences were significant at the $p=.00$ level. As shown in the table, the three areas in which this overestimation was the greatest were in Financial Aid (-3.52), Host Language (-2.69), and Health and Safety (-2.58). More importantly, though the differences between expectations and reality were statistically significant, they were still fairly small, suggesting that the students were reasonably accurate in their predeparture expectations. In addition to presenting these differences by problem area, independent sample $t$ tests were also used (at the $p=.05$ level) to check for categorical as well as individual differences between students at the two schools. 
Table 11

Overall Mean Change Rankings of Categories Indicating Change in Expectations of the Reentry Survey From the Predeparture Survey

\begin{tabular}{|l|c|c|c|}
\hline Category & $\begin{array}{c}\text { Average } \\
\text { Mean } \\
\text { Change }\end{array}$ & Private & Public \\
\hline 1. Financial Aid & -3.52 & -4.45 & -2.59 \\
\hline 2. Host Language & -2.69 & -4.73 & -0.65 \\
\hline 3. Health and Safety & -2.58 & -3.58 & -1.58 \\
\hline 4. Orientation Services & -2.46 & -3.39 & -1.53 \\
\hline 5. Student Admission/Selection & -2.37 & -3.45 & -1.29 \\
\hline 6. Social-Personal & -2.16 & -3.06 & -1.25 \\
\hline 7. Religious Services & -2.09 & -0.56 & -0.65 \\
\hline 8. Living and Dining & -1.38 & -1.93 & -0.83 \\
\hline 9. Student Activities & -1.29 & -1.81 & -0.78 \\
\hline
\end{tabular}

Note. Significant differences between the private and public universities were found in the categories of Living and Dining (0.00), Student Admission/Selection (0.05), Health and Safety (0.03), and Host Language (0.00).

As shown in Table 11, the largest change occurred in the area of Financial Aid (-3.52), indicating that the costs and finances of the study abroad experience were not as worrisome as expected. In this category, two of the top three issues did not change from predeparture to reentry and these were the concerns about "a lack of money for travel" (1.07) and the "limited buying power of the dollar" $(0.96)$.

To determine the extent to which these changes are related to the specific countries visited, independent sample $t$ tests were used to compare developed versus developing nations. This analysis was based on the country's Gross Domestic Product in 2006 as reported by the Central Intelligence Agency's (2008) Factbook; however, no significant differences were found between those students visiting developed countries versus those visiting developing countries. There were, however, significant Financial Aid differences between European and non-European sojourners. For example, those 
visiting European countries experienced larger changes in the following four specific areas: "lack of money for travel $(p=.01)$, "not receiving enough money from home" ( $p \geq .00)$, "not having enough money for social events" $(p \geq .05)$ and "problems shopping in the host country" $(p \geq .05)$.

The category of Host Language (-2.69) was the second greatest area of problem overestimation for the private and public university students. Specific issues raised were "speaking the host nation language" ( 0.96 vs. 0.96 with no change), "understanding the host nation language" ( 0.95 vs. 0.96$)$, and "ability to read the host nation language" $(0.85$ vs. 0.76). In this category, significant differences existed between the private and public university students regarding "reading, comprehension and presentations in the host country language," where the private university students were more worried about their capabilities than the public university students ( 0.49 vs. 0.06$)$.

In the area of Health and Safety (-2.58), the concerns of "being a foreign student" and "the feeling of tension and stress" were consistently rated as the number one and two concerns at both predeparture and reentry. In addition, there were significant differences between the private and the public universities in this category over the issue of "global war against terrorism," with the private school mean of 0.39 versus the public university mean value of 0.14

In the category of Orientation Services (-2.46), there were two major concerns that remained throughout the study abroad period. The first issue was "registration," with a mean of 0.85 at predeparture and a mean of 0.81 at reentry. The second realization was "being accepted in social groups," with a mean of 0.84 at departure and a mean of 0.59 
upon arrival home. There were no significant differences between the private and public university students.

The top three issues in the category of Student Admission Selection (-2.37) remained the same from predeparture to reentry. These were the issues of "GPAs" (1.18 vs. 1.24), "concern about being a foreign student" (1.10 vs. 0.97), and "writing term papers" (1.05 vs. 0.77$)$. The GPA issue was the only concern that registered a higher mean score at reentry than at departure. Additionally, there was one significant difference in the mean change and this was for the issue of "study abroad was not what was expected," with the means of 0.09 versus 0.66 , respectively, for the private and public universities.

In the area of Social-Personal (-2.16), the issues constant to both predeparture and reentry private and public university students were "homesickness" (1.23 vs. 0.94$)$ and "being lonely" (1.13 vs. 0.92). In both cases each of these issues rated as the number one and two concerns, respectively. There were no significant differences between the private and public university students.

The category of Religious Services (-2.09) had two issues that remained from departure through reentry and those were the issues of "lack of knowledge about the host country religion" ( 0.92 vs. 0.51$)$ and "study abroad spirituality was not what was expected" $(0.58$ vs. 0.46$)$. There were no significant differences between the two universities in this category.

In the area of Living and Dining (-1.38), only the issue of "problems regarding housing" ( 0.88 vs. 0.83$)$ was noted as an issue of concern at both departure and reentry. Significant differences between the private and the public universities were found in the 
"taste of food" ( 0.77 vs. 0.44$)$, "types and comfort of accommodations" ( 0.86 vs. 0.36$)$, "daily traveled distances to school" ( 0.89 vs. 0.29$)$, and "the perceived lack of appropriate housing," with a mean score of 0.00 for private school students as compared with 0.38 for the public university students.

In the final category of Student Activities (-1.29), there were three concerns that remained throughout the study abroad experience for both groups of students; these were “opportunities to meet host nation people" ( 0.68 vs. 0.76$)$, "trying to meet new friends" (0.88 vs. 0.66$)$, and "attitudes of some against American students" ( 0.85 vs. 0.54$)$. There were no significant differences between the private and public university students with this category.

Table 12 shows the top eight predeparture issues regardless of categories. It is interesting to note that seven of the top eight remained valid concerns upon reentry; in fact, only the worry of "unexpected financial needs" was not rated within the top eight upon reentry from study abroad, suggesting that financial needs were dealt with appropriately during the study abroad period and were not a concern upon reentry.

Table 12

Differences in Category Issues Predeparture and Reentry

\begin{tabular}{|l|c|c|}
\hline Concern & $\begin{array}{c}\text { Rank } \\
\text { Predeparture }\end{array}$ & $\begin{array}{c}\text { Rank Upon } \\
\text { Reentry }\end{array}$ \\
\hline Lack of money for travel & 1 & 2 \\
\hline Homesickness & 2 & 6 \\
\hline Concerned about GPA & 3 & 1 \\
\hline Unexpected financial need & 4 & Not ranked \\
\hline Being lonely & 5 & 7 \\
\hline Concern about being a foreign student & 6 & 3 \\
\hline Limited buying power of the dollar & 7 & 4 \\
\hline Speaking host country language & 8 & 5 \\
\hline
\end{tabular}


In summary, there were many issues that the students originally worried about at departure that remained worrisome throughout the study abroad experience. These major issues were the lack of money for travel, homesickness, concern about GPA, being lonely, concern about being a foreign student, limited buying power of the dollar, and the ability to speak the host country language. However, most importantly, all of the problems both expected and encountered were either minor or nonexistent.

\section{Research Question 4: What kind of adjustment challenges were experienced}

\section{upon reentry?}

Post experience perceptions--what happens when you come home from living abroad — has interested researchers for over 50 years. Originally, it was seen as a set of problems that returnees faced often, ranging from linguistic barriers to the inability to settle down to the routine of school or work. It is now common to think of reentry as a positive challenge and as an opportunity for growth and self-discovery. Moreover, it is an important part of the study abroad experience. In fact, the importance of post experience perceptions cannot be overstated for this is where the students use their new-found skills of independence, flexibility, and sophistication in search of a lifetime vocation. The challenge lies in how institutions use reentry as a learning experience.

The question of the reentry experience was the main topic of discussion with the focus groups. There were two separate focus groups of 5 students each from both the private and public schools. The private school focus group had 4 females and 1 male member, while the public school focus group consisted of 2 males and 3 females. The survey and focus group asked the students to reflect upon the first 3 days back in the United States. During that initial period, according to the results of the reentry survey, 
both females (1.26) and males (1.24) felt disoriented. However, females tended to report feeling more isolated during their first few days back than males.

Focus group discussions reflected on the quantity and quality of social, personal, and academic changes experienced during their time abroad. During these discussions, females reported significantly more social changes than males. In terms of questions, on average, females stated that they noted "quite a bit" of social changes, whereas males noted "an average amount of social changes." Female students tended to view the quality of social change as "mixed," while male students generally viewed the social changes as more positive.

Similarly, focus group discussions indicated that female students were especially sensitive to the changes in their social networks. A student returning from a semester abroad in Japan described her experience as follows:

The first week just sort of passed in a daze. People would stop and say "Oh, Hi ... how have you been?" ... and they remembering me ... and me like not necessarily remembering their names ... pretty much on autopilot.

My social sphere was definitely readjusted since I got back ... it is nothing like it used to be.

Actually I don't think I realized that anybody had any of the same emotions that I did until about a month later when one of my newer friends, who had actually been in China the semester before, said, "Do you feel as horrible as I do? . . . and I said, "Oh, you do too? ... then we talked about it.

The first 2 weeks were the worst ... and I was really depressed ... sometimes I still feel very displaced, and like you don't belong anywhere.

Another student anticipated reentry difficulties enroute from China. Although she expected shifts in her social network, the changes were nevertheless difficult for her to cope with: 
I was really nervous on the plane ride over... I knew one of my really good friends was going abroad for the semester.

It was just really different ... I felt a sense of loss ... then I looked around and the buildings were all the same, the environment was the same, but the people were totally different ... and the friends that I do know here are all into their own things, and so much time has passed that for them, things have kept going on, and for me, I came back here just picking up where I left off . . . and they've already passed that ... I felt disconnected.

Something was definitely missing, I didn't know what ... I still had my regular work and things like that, but I just felt displaced.

Another student, returning from Spain, described the frustration she experienced

while trying to maintain her ties to her friends who had not been abroad:

My friends didn't understand the experience ... they would say, "So, it's weird being back?" and I would say. "Yeah, it is really weird ... and then a week later they expected me to be fine again ... and a month later, I'm just getting over it, and they're like, "What's wrong with you? You are kind of weird." And I'm like, "I know ... I am just trying to get back into it.

In contrast, a male student returning from Ireland expressed less frustration about the changes in his personal life. When asked how his interactions were with his friends, he responded:

Yeah, I mean I talk about it with them . . . in some ways it's kind of odd because my group of friends has kind of shifted between last year and this year ... and I knew it would happen because a large portion of my friends that I used to hang out with are abroad now ... so, I mean I saw it coming a long time ago ... so that shift doesn't really have anything to do with me going abroad ... but it doesn't really seem to have affected too much the way I am interacting with people now.

Another student stated that:

When I came home, it was hard for me to discuss my experiences with my family and friends for they could not relate. I found comfort in finding students with similar experiences to hang out with. 
A female student from the private school was concerned that there were no activities for them upon their return:

We were all invited to a picnic to share experiences, but only a few people showed up. That was the only effort by the study abroad office to get us together.

Another student gave an interesting perspective:

I was anxious to get home and return to school . . . but once I got home, the juices started flowing and I wanted to go abroad again. I missed the challenges and my independence.

Thus, a pattern emerged from the survey responses and focus group discussions, in which returning female students appeared to experience more disorientation, isolation, and changes in their social networks than their male peers. Despite the greater social disruption that the females experienced during reentry, they looked back on their study abroad in a positive light and felt they would most likely look for new opportunities to pursue another study abroad program or find other international vocations and opportunities available to young adults. 


\section{CHAPTER 5}

\section{THE FINDINGS AND CONCLUSIONS}

\section{Introduction}

This chapter will summarize the main findings of the dissertation and contextualize these findings in the relevant literature. The discussion will also present recommendations and implications for future study abroad programs located within higher education institutions. This section will then conclude with some suggestions for future research on the subject of cultural adaptations of students participating in study abroad programs.

Over the past decade, the growing number of study abroad students has created an incentive for universities to evaluate their programming, services, and policies for these students in order to determine if the university is responding well to the needs of both students and institution (Hey-Kyung, 2006). Such an evaluation is necessary because study abroad students are confronted with numerous challenges as representatives of our nation abroad. Faced not only with personal challenges and the challenges of daily living, study abroad students are also faced with the elements of culture shock as defined by Kaufman et al. (1992).

As Church (1982) suggests, there is much added stress in the lives of study abroad students as a result of living in a different culture. Arthur (2004) expresses the seriousness of this need for an evaluation when he suggests

if America wishes to maintain global presence and influence, it is time that our institutes of higher learning think seriously of how best to maximize the value of study abroad programs by doing more than sending them into the field. (p. 72) 
From an institutional perspective, universities need to do more than "merchandise" the value of spending time abroad. For the maximum benefits to study abroad students there must be follow-up programs that address the major concerns of students upon reentry.

In addition to the importance of institution-based policies that support the study abroad experience, students, of course, must assume some responsibility themselves. The results of this study suggest that adjustments and adaptations made by students were critical to their success; for example, language is one issue that is relevant both inside and outside the classroom. This study also suggests, as was brought out through focus group discussions, that those students with host language skills did not suffer from a lack of social development.

There is also the problem of culture shock, including the emotional stress that comes from feelings of social isolation, loneliness, depression, and anxiety. These problems are sometimes so intense that they can become health factors as Pedersen (1995) suggests. In this study, the students experienced cross-cultural problems, financial challenges, and social-personal issues during their sojourn abroad.

The importance of this research is twofold; it has provided both universities with the opportunity to evaluate their effectiveness in working with study abroad students and it has given those students an opportunity to express their concerns to the universities involved. It also has added some empirical evidence regarding the study abroad experience to the literature, which here-to-fore has been sorely lacking. 
The Summary of the Findings

With respect to the demographics of the study, research indicates that the sample used in this study closely matched the national profile of all students who studied abroad during the time period of this study. For example, as described in the Institute of International Education publication, Open Doors 2006 (Hey-Kyung, 2006), the typical profile of the 2005-2006 study abroad student was one who studied liberal arts (62.5\%), completed a semester abroad (47.5\%), was 20 years old (55.8\%), was female (65.5\%), and was of Caucasian ethnicity (83.5\%). As seen in Table 1, this closely matches the overall student population used in this study since they were mostly liberal arts students (65.7\%), completed a semester abroad (50\%), were 20 years old (56.1\%), were female $(84.5 \%)$, and were Caucasian (67.5\%).

As described earlier, the main finding of this study was that students at the two participating schools viewed their study abroad problems as relatively minor. In addition, mean scores in each of the problem areas were lower upon reentry than at departure, with the public school students scoring lower than students from the private school. This finding suggests that the public school students were slightly better prepared in their expectations than those of the private school.

With respect to the survey's findings about predeparture expectations, there was insufficient evidence to support the theories of culture shock as defined in Oberg's (1960) W-curve theory. Simply stated, Oberg's W-curve describes a pattern of adjustment which occurs in five phases that take the form of the letter "W." On the left side, the high end is the "honeymoon" first phase where the traveler is excited about preparing for travel and being in a new place. Next is the "emptiness or rejection second phase," which is on the 
left side, low end of the "W," where even small differences in the host country grate on the traveler. The next step is the third phase, located on the "W" high right side, and is called the "acceptance phase," where the traveler gains some understanding of the new culture and accepts food, drinks, habits, and customs. The fourth phase is the "reverse culture shock phase," found on the low right side of the "W," where the traveler tries to assimilate back into the home culture. The fifth phase, which completes the "W," is when the traveler uses the experience for new benefit of work or eventual return to international travel (Oberg, 1960). However, the findings of this study suggest that, for at least this population, Oberg's theory may not be accurate; in fact, study abroad advisors may wish to weigh the importance of warning students about potential frustrations with the study abroad experience against the possibility of needlessly increasing the students' predeparture anxiety levels.

There were, however, specific findings that did support the need for better orienting students in specific categories prior to departure. For example, the concern about Financial Aid was very significant relative to the other categories, although the overall mean scores were low. This would indicate that there was more concern about finances from predeparture through reentry. In addition, it is interesting to note that the apprehensions throughout the study were about the "lack of money for travel" $(0.53)$, followed by "unexpected travel needs" (1.14) and "the limited buying power of the dollar" (1.09). Upon return, Financial Aid concerns were essentially the same but with lower mean scores; "the lack of money for travel" remained the number one concern (1.07), followed by the "limited buying power of the dollar" $(0.96)$ and a new concern of "not having enough money for social events" was the number three concern (0.75). 
The number one concern for returning students was found in the Social-Personal category. The issue of "homesickness" (0.94) was the top concern, followed by the "sense of being lonely" $(0.92)$ and the "challenge of meeting new host nation friends" $(0.80)$. In fact, two out of these three concerns were also represented in the predeparture survey, although with higher mean scores. Specifically, the predeparture anxiety was "homesickness" (1.23), followed by the "sense of being lonely" (1.13) and "nervousness" (0.93). Based on focus group conversations, there was a direct correlation between social adjustment and language-speaking capabilities.

The Host Language category issues did not vary between both the predeparture and reentry surveys. Upon departure and reentry, the students rated their first concern to be the "challenge of speaking the host nation language comfortably" $(0.96)$. The second issue was "the ability to comprehend the host nation language." This, too, had the same 0.96 score for both surveys. The third issue was "the ability of the student to read the host nation's language" at departure $(0.85)$ and upon reentry $(0.76)$. This relationship between the Social-Personal and the Host Language supports Ward and Kennedy's (1993) observation that language proficiency is closely related to the amount of social interaction with locals and correlated to a lesser degree with general satisfaction about their experience and their cultural adjustment.

A final area in which this research suggests ways to improve the study abroad experience concerns the reentry period. Discussions with returning students clearly pointed to the need for more reentry support services. Some students viewed the return to campus as somewhat of a setback in their personal development. In the words of one returning student: 
When I move, or change locations, I feel like I'm taking a step forward . . . But then to take that step into Spain and then come back to the same place, it felt like a step backwards almost ... it was really hard.

In order to help students view the return to campus as an opportunity for continued growth, it may be necessary to provide additional support services to returning students. Students commented that they would appreciate more than "a one-time welcome-back picnic.” Apparently, a little more would go a long way for the students. When asked whether reentry discussion groups would be helpful, focus group participants suggested that they did not need such extensive support from study abroad staff or campus counselors. Rather, they expressed a desire for the study abroad office to facilitate networking among returning students in order that they might provide social support to one another whenever the transition back to campus life became particularly challenging. A returning student suggested that an initial welcome-home dinner might serve as an opportunity for students to establish bonds with others who traveled to similar cultures, which might help the student cope with later reentry difficulties and challenges. In the words of a returning student:

When you get back, it's not that you don't want to talk about it, but you want to talk about it in depth ... and if you talk to somebody who's been somewhere similar, you don't have to explain everything, and you now that they understand ... I think you feel a lot more comfortable with those people, and if you do have [difficulty with] things, you feel a lot more comfortable calling them later, and saying, "Okay, this is weirding me out."

\section{Significance of the Study}

The significance of this research is that there are very few empirical studies that describe the problems brought about by the effects of culture shock on study abroad students. Most of the research measures the culture shock of international students who 
attend colleges and universities in the United States. As such, this study provides university officials, tasked with the responsibility of maintaining quality international study abroad programs, insight as to whether or not the needs of their students are being met. The desired result will be that the universities involved will either revise or initiate new programs that enhance the acculturation success of the students enrolled in study abroad programs. It would be useful for students preparing for their studies abroad to have a variety of different informational sources that might help them prepare for what lies ahead and the challenges upon their return home.

\section{Delimitations and Limitations}

It was anticipated that data for this study would be obtained from a diverse group of students (from the two universities) who traveled to various destinations throughout the world. As such, results should generalize well for students across study abroad destinations and programs. However, several aspects of this study should be kept in mind when ascertaining to whom and under what circumstances these findings are most relevant. According to the literature review, and as supported by the demographical data of the survey, most of the participants of study abroad programs are approximately 20 years old, female, and from high-income families and many have traveled to Western European countries (Hey-Kyung, 2006). Beyond these identifiable aspects of the current sample, other aspects limit the ability to generalize. For example, U.S. study abroad participants undergo a unique set of circumstances; some of the more important aspects of these circumstances are that the study abroad participants move temporarily to a new country because they voluntarily chose to do so. Additionally, they move with relatively small concern for their financial security and are working under the assumption that they 
are, at most, on a semester-long limited absence from the United States. Moreover, most do not have to contend with the challenge of seeking social networks in a foreign country since most study abroad programs and host universities provide built-in opportunities for engaging in social activities.

Another limitation of this study includes the fact that the participants self-report their level of adjustment, which may or may not be an accurate reflection of the true adjustment process. In addition, although the numbers of participants in the current study are appropriate for the statistical methods employed, they represent a small sample of the overall numbers of students embarking on a study abroad program, particularly concerning the small number of men participants at the private university; as such, all generalizations should be made with caution.

A further limitation, which may account for the low anxiety level of the predeparture students, was the fact that majority of this self-selected population had prior international travel experience. For example, over $70 \%$ of the respondents indicated that they had visited other countries, although the majority of the students had traveled to Mexico, which is located near both the public and private universities. For future studies, it would be interesting to limit the surveys to those who had never traveled beyond the borders of the United States, which would give a true indication of cultural adjustment for that particular study abroad experience.

Finally, students have special goals and expectations as college students studying abroad. Their experiences are not likely to parallel those of adults sojourning abroad to pursue personal or career goals. Any effort to compare results with those adult travelers should be mindful of important differences in sojourner selection, support, and duration 
of the sojourn. Additional concerns may also be raised about participant attrition. Further, there may be a group of students who decided to stay on and travel upon completion of their studies, therefore affecting the full range of reentry expectations and survey participation.

\section{Implications and Applications of Future Studies}

In retrospect, there were many lessons learned from this study that should be considered for future efforts about the subject of study abroad and personal expectations. In this section, the most important implications will be discussed.

The first implication concerns the MISPI survey instrument as developed by Dr. John Porter and modified with his permission. The instrument was rather lengthy and asking students to respond twice (at predeparture and reentry) was optimistic; in fact, a better method would have been to provide an abbreviated version of the questions without once again asking the redundant questions found in the background information. Also, the qualitative questions at the end of the reentry survey only added to the length and frustration of the busy student. Students were eager to help with the focus groups and this would be a better source of qualitative information.

The second implication would be improvement on the actual survey instrument. There would certainly have been a much better rate of return if the students were required by study abroad staff to complete such a survey as a part of the study abroad experience. This would best be conducted during mandatory meetings of all participants at predeparture and within a week of reentry. In this study, there were 200 respondents who completed all of the predeparture surveys, while there were 114 who completed both. 
The third implication involves the association with the study abroad staff. Although both the private and public universities were supportive of this study, only the public school provided full access to students, facilities, and information. The private school, however, provided only a few minutes of coordination during their mandatory meetings, making it difficult to express to all students the importance of the survey for future programs. The project coordinator at the public school was very interested in the survey and actively outcome of the study.

The fourth implication involves focusing research on questions that were not focal points here. The following is the most obvious question:

1. Why are there low participation rates for African American students in Study Abroad? (Both the national average and the mean of minority students reflected in this study is less than $2 \%$.)

The final implication entails expanding the research methods used. This expansion should include using inferential as well as descriptive analysis with quantitative data. Inferential analysis could answer questions such as:

1. What would the predeparture and reentry surveys reflect for those students who have never travelled outside the borders of the United States?

2. What would the results of multivariant regression analysis indicate by comparing gender, locations, ethnicities, and language capabilities?

Future studies also should use qualitative methods to a greater extent than the qualitative methods used in this study. It is interesting to note that virtually all the recommendations for policy and practice presented in this chapter come from the two quite limited focus group interviews. 


\section{Conclusions}

There are many challenges for the study abroad offices as students and parents demand interesting, enjoyable programs in, of course, safe locations. Academic administrators seek strong educational programs consistent with the institutional values. Further, there is pressure to increase the numbers of students who participate. The key to a successful study abroad program is the establishment of a strong preparation program that will provide the student with a broad range of skills and understanding. These advantages are often taken for granted by the student. They must be alerted to the fact that study abroad can both hurt and help your career, depending how they approach the experience. Consequently, study abroad offices are urged to partner with campus career services offices to educate students about the potential value of the experience and how skills obtained abroad can be used for the student's benefit.

To assist in gaining career advantages as well as assist in the challenge of reentry adjustment, students should be asked to write more than a simple essay. They need to demonstrate to the study abroad staff a true commitment to study in a particular country. This can be easily demonstrated by taking advantage of advanced language classes of the country; taking courses in history, sociology, and political science that focus on the region to be visited; and reading newspapers and magazines from the country, which can be found in school libraries and the internet. Students can also take the initiative to identify an independent study or internship that compliments the foreign study.

In addition, universities should require that study abroad students engage with international students from the country of their interest. Both the private and public universities have sufficient numbers of foreign students to chat with prospective study 
abroad students. The issue of assessment of study abroad students should be a critical part of the study abroad program. It is very important that students' understanding and their learning be assessed before they go and upon their reentry into the United States. Post assessment work should be a prerequisite to obtaining credit for the study abroad experience. This can take the form of reflective journals which can be shared by the students in group study. This would serve as an important aid in helping the students readjust to returning home. There will be important benefits to the students who can share with their friends the impact of international experiences on their lives and careers. 


\section{References}

Adler, P. (1975). The transitional experience: An alternative view of cultural shock. Journal of Humanistic Psychology, 15, 12-23.

Arthur, N. (2004). Counseling international students: Clients from around the world. New York: Kluwer Academic/Plenum.

Bikson, T., Treverton, G., Moini, J., \& Lindstrom, G. (2003). New challenges for international leadership. New York: Rand.

Center for International Business Education and Research. (2008). About CIBER. Retrieved March 20, 2008, from http://www.bus.wisc.edu/ciber/home/ home.asp?hometopic $=$ about

Central Intelligence Agency. (2008). Factbook: Guide to country profiles. Retrieved February 24, 2008, from https://www.cia.gov/library/publications/the-worldfactbook/docs/profileguide.html

Church, A. (1982). Sojourner adjustment. Psychological Bulletin, 112(1), 155-159.

Fitzgerald, V. F. (1998). The identification of problems in academic and social support systems by international students. Unpublished doctoral dissertation, University of Iowa, Iowa City.

Furnham, A., \& Bochner, S. (1986). Culture shock: Psychological reactions to unfamiliar environments. London: Methuen.

Galloway, F. J., \& Jenkins, J. R. (2005). The adjustment problems faced by international students in the United States: A comparison of international students and administrative perceptions at two private, religiously affiliated universities. NASPA Journal, 42(2), 175-187.

Germann, C., \& Krupar, K. (2002, April). The challenges of global learning in the new digital age. Paper presented at the Learners Without Boundaries, College Without Walls Conference, Metropolitan State College, Denver, CO.

Green, M. (2000). Toward comprehensive internationalization: An ACE initiative for undergraduate education. Washington, DC: American Council on Education.

Green, M., \& Olson, C. (2003). Internationalizing the campus: A users guide. Washington, DC: American Council on Education.

Grosvenor, G. (1988, June). Americans get low grades in Gallup geography test [Special issue]. National Geographic Society, 54-55. 
Gullahorn, J. T., \& Gullahorn, J. E. (1963). An extension of the U-curve hypothesis. Journal of Social Sciences, 19(3), 33-47.

Hebel, S. (2002). National security concerns for congressional interest in language programs. Chronicle for Higher Education, 17, 48.

Hess, I. D. (2002). The whole world guide to cultural learning. Yarmouth, ME: International Press.

Hey-Kyung, K. C. (Ed.). (2006). Open Doors 2006: Report on international education exchange. New York: Institute of International Education.

Jenkins, J. R. (2001). Perceptions of international students and university personnel of cultural adjustment problems at two private universities. Unpublished doctoral dissertation, University of San Diego, CA.

Kauffmann, N., \& Lysgaard, S. (1955). International Social Science Bulletin, 7, 45-51.

Kauffmann, N., Martin, J., \& Weaver, H. (1992). Students abroad, strangers at home: Education for a global society. Yarmouth, ME: Intercultural Press.

Kealey, D. J. (1989). A study of cross-cultural effectiveness: Theoretical issues, practical applications. International Journal of Intercultural Relations, 13, 387-428.

Kirwan, W. (2004). What makes racial diversity work in higher education. Sterling, VA: Stylus Press.

Kohls, R. (2001). Survival kit for overseas learning: For Americans planning to live and work abroad. Yarmouth, ME: Intercultural Press.

Lewis, R. D. (2003). When cultures collide: Managing successfully across cultures (2nd ed.). London: Nicholas Brealey.

Marshall, T. (1989). The whole world guide to language leaning. Yarmouth, ME: Intercultural Press.

Martin, J., \& Weaver, H. (1992). Students abroad, strangers at home: Education for a global society. Yarmouth, ME: Intercultural Press.

Marx, E. (2001). Breaking through cultural shock. Yarmouth, ME: Intercultural Press.

Mattau, P. R. (1989, November). Some mitigating factors against African-Americans in rural American south opting to study abroad. Paper presented at the annual conference on the International Educational Exchange, Washington, DC. 
National Association of Foreign Student Advisors. (2003). An international education agenda for the United States: Public policy, priorities, and recommendations. Washington, DC: Author.

National Resource Center. (2008). National Resource Center program. Retrieved February 24, 2008, from http://www.ed.gov/programs/iegpsnrc/index.html

Novell, J. R. (1994). Coping strategies of Claremont students returning from studies abroad. Unpublished doctoral dissertation, Claremont McKenna College, CA.

Oberg, K. (1960). Cultural shock: Adjustment to new cultural environments. Practical Anthropology, 7, 177-182.

Oblinger, D. (2002, April). The web, WAP and a world view. Paper presented at the Learners Without Boundaries, College Without Walls Conference, Metropolitan State College, Denver, CO.

Paige, R. (1993). Education for the intercultural experience. Yarmouth, ME: Intercultural Press.

Paige, R., \& Martin, R. N. (1996). Ethics in intercultural learning: Handbook of intercultural learning (2nd ed.). Thousand Oaks, CA: Sage.

Pedersen, P. (1995). The five stages of culture shock. Westport, CT: Greenwood Press.

Pickert, S. (1992). Preparing for a global community: Achieving an international perspective on higher education. East Lansing, MI: National Center for Research on Teacher Learning. (ERIC Document Reproduction Service No. ED350971)

Porter, J. W. (1962). The development of an inventory to determine the problems of foreign students. Unpublished doctoral dissertation, Michigan State University, Lansing.

Porter, J. W. (1993). Michigan international student inventory: The manual. Lansing, MI: Michigan State University.

Raschio, R. (1987). College students' perceptions of reverse culture shock and re-entry adjustments. Journal of College Student Personnel, 28(2), 156-162.

Saltzman, A., \& Mulrine, A. (1996, April 8). Road less traveled: Developing nations are new magnets for collegians studying abroad. US News and World Report, 18, 5758.

Twain, M. (1869). Innocents abroad. Hartford, CT: American. 
Voght, G., \& Schaub, R. (1993). Foreign languages and international business. East Lansing, MI: National Center for Research on Teacher Learning. (ERIC Document Reproduction Service No. ED347851)

Ward, C., Bochner, S., \& Furnham, A. (2001). The psychology of culture shock (2nd ed.). East Sussex, UK: Routledge.

Ward, C., \& Kennedy, A. (1993). Psychological and socio-cultural adjustment during cross-culture transitions: A comparison of secondary students overseas and at home. International Journal of Psychology, 28(2), 129-147.

Westwood, M., Lawrence, W., \& Paul, D. (1986). Preparing for re-entry: A program for the sojourning student. International Journal for the Advancement of Counseling, 9(3), 221-230.

Winkleman, M. (1994). Cultural shock and adaptation. Journal of Counseling \& Development, 73(2), 121-126. 
Appendix A

Michigan International Student Problem Inventory 


\section{Michigan International Student Problem Inventory}

(As devised by John Porter and modified by Walt Heinecke)

[Responses to this survey are CONFIDENTIAL, and NO student names will be released. Participation in this survey is VOLUNTARY. This is not a test. There is no right or wrong answers.]

\section{Step One: PERSONAL INFORMATION}

Directions: Please answer the following questions by either filling in the blanks or circling the appropriate response.

Today's Date

1. What country will you be visiting?

2. What university will you attend in the host country?

3. Are filling this out: At the start of the program? At the end of the program?

4. Is the program you are in which you are participating Summer only? One semester? One year? Other (describe)

5. Does the program have an internship component:

6. What is the purpose/name of the program in which you are participating?

7. Living Arrangements: With a family

Dormitory

In community

8. Did you attend an orientation?

Yes

No

9. What type of school do you attend?

Private University

Public University

10. What is your role?

Faculty

Student

Other 
11. What is your highest degree?

GED/High School AA BA/BS Masters Ph.D/Ed.D/JD/MD

12. For what degree are you currently studying?

GED/High School AA BA/BS Masters Ph.D/Ed.D/MD/JD

Major/Degree Program

13. What is your age? years

14. What is your gender? $\quad$ Female

15. What is your home state or country of origin?

16. Is the community you come from: Rural Urban Suburban

17. Please circle the ethnic group that you most identify with:

$\begin{array}{ll}\text { African-American } & \text { Hispanic } \\ \text { Indigenous/first peoples } & \text { European } \\ \text { Asian } & \text { Middle Eastern } \\ \text { Asian-American } & \text { Other. What? } \\ \text { Caucasian, White } & \end{array}$

18. What is your native language?

19. Have you ever traveled abroad before this experience? Yes No

If yes, how many times have you traveled abroad?

If yes, how long were these trips abroad (on average)?

20. Had you taken classes in the host language?

Yes

No 
21. How would you rate your language proficiency in the host language? (circle one)

$100 \%$ fluent

$75 \%$ fluent

$50 \%$ fluent

$25 \%$ fluent

I don't know the language at all

22. What was your primary reason for participating in the study abroad program? (Please circle one)

To obtain university/college transfer credit

To take courses to lead to a degree

To experience a new culture

To have fun

23. How did you learn about the study abroad program? (Please circle the most appropriate)

University advertising

Family recommendation

Friend recommendation

Internet

Other (Please list) 


\section{STEP TWO: SURVEY QUESTIONS}

Directions: Please read each of the following 99 statements carefully. Circle $0,1,2$, or 3

\begin{tabular}{|lll}
\hline 1. & Circle 0 if the statement suggests & NO PROBLEM \\
2. & Circle 1 if the statement suggests & MINOR PROBLEM \\
3. & Circle 2 if the statement suggests & MODERATE PROBLEM \\
4. & Circle 3 if the statement suggests & MAJOR PROBLEM \\
\hline
\end{tabular}

1. Concern about my GPA as a measure of success

2. Treatment received during orientation meeting

3. Unfavorable remarks about the USA

\begin{tabular}{cccc}
\multicolumn{2}{c}{ No Problem } & \multicolumn{2}{c}{ Major Problem } \\
0 & 1 & 2 & 3 \\
0 & 1 & 2 & 3 \\
0 & 1 & 2 & 3
\end{tabular}

4. Concept of being a "foreign student"

5. Concern about being too "Westernized"

6. Insufficient personal - social counseling

$\begin{array}{llll}0 & 1 & 2 & 3 \\ 0 & 1 & 2 & 3 \\ 0 & 1 & 2 & 3\end{array}$

7. Being in love with someone

8. Taste of food in host country

9. Problems regarding housing

$\begin{array}{llll}0 & 1 & 2 & 3 \\ 0 & 1 & 2 & 3 \\ 0 & 1 & 2 & 3\end{array}$

10. Being told where you must live

11. Poor eye sight

12 . Recurrent headaches

$\begin{array}{llll}0 & 1 & 2 & 3 \\ 0 & 1 & 2 & 3 \\ 0 & 1 & 2 & 3\end{array}$

13. My physical height and physique

14. Religious practices in host country

15. Attending church functions

$\begin{array}{llll}0 & 1 & 2 & 3 \\ 0 & 1 & 2 & 3 \\ 0 & 1 & 2 & 3\end{array}$

16. Concern about my religious beliefs

17. Speaking the native language

18. Ability to write in the host country language

$\begin{array}{llll}0 & 1 & 2 & 3 \\ 0 & 1 & 2 & 3 \\ 0 & 1 & 2 & 3\end{array}$

19. Regulations on student activities

20. Treatment received at social occasions

21. Relationship of men and women in the host country

22. Lack of money to meet expenses

23. Not receiving enough money from home

24. Not enough time to study

$\begin{array}{llll}0 & 1 & 2 & 3 \\ 0 & 1 & 2 & 3 \\ 0 & 1 & 2 & 3\end{array}$


25 . Trying to extend stay in host country

26 Registration for classes

27. Relationship with study abroad advisor

\section{No Problem}

0

0

0

28. Leisure time activities of host nation students

29. Law enforcement practices in host country

30. Insufficient advice from academic advisor

31. Being lonely

32. Feeling inferior to others

33. Trying to make friends

34. Cost of buying food

35. Insufficient clothing

36. Not being able to room with a U.S. student

37. Hard to hear

38. Nervousness

39. Finding adequate health services

40. Finding a worship group of own faith

41. Christianity in host country

42 Variety of religious faiths in host county

43. Reciting in class

44. Understanding lectures in host country language

45. Reading text books written in host language

(0)

$$
0
$$

0

Major Problem

3

3

3

3

3

3

3

3

3 3

$\begin{array}{llll}0 & 1 & 2 & 3 \\ 0 & 1 & 2\end{array}$

$\begin{array}{llll}0 & 1 & 2 & 3 \\ 0 & 1 & 2 & 3 \\ 0 & 1 & 2 & 3\end{array}$

$\begin{array}{llll}0 & 1 & 2 & 3 \\ 0 & 1 & 2 & 3 \\ 0 & 1 & 2 & 3\end{array}$

46. Dating practices of host country people

47. Being accepted in social groups

48. Not being able to find "dates"

49. Having enough money for social events

50. Limited buying power of the U.S. dollar

51. Being American

52. Changes in host country government

53. Host country rules and regulations

54. Lack of knowledge about the host country

$\begin{array}{llll}0 & 1 & 2 & 3 \\ 0 & 1 & 2 & 3 \\ 0 & 1 & 2 & 3\end{array}$

$\begin{array}{llll}0 & 1 & 2 & 3 \\ 0 & 1 & 2 & 3 \\ 0 & 1 & 2 & 3\end{array}$

$\begin{array}{llll}0 & 1 & 2 & 3 \\ 0 & 1 & 2 & 3 \\ 0 & 1 & 2 & 3\end{array}$


55. Campus size

56. Host country emphasis on time and promptness

57. Sexual customs in host country

No Problem

58. Homesickness

59. Feeling superior to others

60. Bathroom facilities cause problems

61. Distances to classes from residence

62. Relationship with roommate

63. Dietary problems

64. Need more time to rest

65. Worried about mental health

66. Having time to devote to own religion

67 Spiritual versus materialistic values

68 Doubting the value of any religion

69 Understanding host country "slang"

70. My limited host country vocabulary

71. My pronunciation not understood

72. Activities of fellow Americans in host country

73 Host country emphasis on sports

74. Problems with shopping in the host country

75. Money for clothing

76. Unexpected financial needs

77. Uncertainties in the world today

78 Desire to go home early

79. Study abroad program not what I expected

80. Not being met on arrival in host country

81. College orientation was insufficient

82. Trying to be a student, tourist and ambassador 83. Attitude of some against American students 84 Host nation emphasis on personal cleanliness

85. Not feeling at ease in public

86. Attitude to some host country to skin color

87. Finding a place to live

0

0

0

Major Problem

3

3

3

$\begin{array}{llll}0 & 1 & 2 & 3\end{array}$

$\begin{array}{llll}0 & 1 & 2 & 3\end{array}$

$\begin{array}{llll}0 & 1 & 2 & 3\end{array}$

$\begin{array}{llll}0 & 1 & 2 & 3 \\ 0 & 1 & 2 & 3 \\ 0 & 1 & 2 & 3\end{array}$

$\begin{array}{llll}0 & 1 & 2 & 3\end{array}$

$\begin{array}{llll}0 & 1 & 2 & 3\end{array}$

$\begin{array}{llll}0 & 1 & 2 & 3\end{array}$

$\begin{array}{llll}0 & 1 & 2 & 3 \\ 0 & 1 & 2 & 3 \\ 0 & 1 & 2 & 3\end{array}$

$\begin{array}{llll}0 & 1 & 2 & 3 \\ 0 & 1 & 2 & 3 \\ 0 & 1 & 2 & 3\end{array}$

$\begin{array}{llll}0 & 1 & 2 & 3 \\ 0 & 1 & 2 & 3 \\ 0 & 1 & 2 & 3\end{array}$

$\begin{array}{llll}0 & 1 & 2 & 3\end{array}$

$\begin{array}{llll}0 & 1 & 2 & 3\end{array}$

$\begin{array}{llll}0 & 1 & 2 & 3\end{array}$

$\begin{array}{llll}0 & 1 & 2 & 3\end{array}$

$\begin{array}{llll}0 & 1 & 2 & 3 \\ 0 & 1 & 2 & 3\end{array}$

$\begin{array}{llll}0 & 1 & 2 & 3 \\ 0 & 1 & 2 & 3 \\ 0 & 1 & 2 & 3\end{array}$

$\begin{array}{llll}0 & 1 & 2 & 3 \\ 0 & 1 & 2 & 3 \\ 0 & 1 & 2 & 3\end{array}$


88. Lack of invitations to visit host nation homes

89. Feeling under tension

90. Service received at health center

\begin{tabular}{cccc}
\multicolumn{2}{c}{ No Problem } & \multicolumn{2}{c}{ Major Problem } \\
0 & 1 & 2 & 3 \\
0 & 1 & 2 & 3 \\
0 & 1 & 2 & 3
\end{tabular}

91. Health suffering due to academic pace

92. Criticism of host country religion

93. Accepting differences in great religions

94. Confusion about United States and host country morals

95 Having a non-English speaking host family

96. Holding conversation with host nation friends

97. Opportunities to meet more host nation people

98. Concern about political discussions

99. This will be a wonderful experience

$\begin{array}{llll}0 & 1 & 2 & 3 \\ 0 & 1 & 2 & 3 \\ 0 & 1 & 2 & 3 \\ 0 & 1 & 2 & 3 \\ 0 & 1 & 2 & 3 \\ 0 & 1 & 2 & 3 \\ 0 & 1 & 2 & 3 \\ 0 & 1 & 2 & 3 \\ 0 & 1 & 2 & 3\end{array}$


Note: This questionnaire is identical to the modified MSIP survey questionnaire taken by study abroad students prior to their departure with the exception of the re-entry questions and the additional open-ended questions regarding re-entry:

Directions: $\quad$ Please read each of the following 5 statements carefully. Circle $0,1,2$, or 3

\begin{tabular}{|lll|}
\hline 1. & Circle 0 if the statement suggests & NO PROBLEM \\
2. & Circle 1 if the statement suggests & MINOR PROBLEM \\
3. & Circle 2 if the statement suggests & MODERATE PROBLEM \\
4. & Circle 3 if the statement suggests & MAJOR PROBLEM \\
\hline
\end{tabular}

1. Feeling uncomfortable about returning home

2. Finding no one at home who can relate to your

No Problem

Major Problem experience

3. Miss that feeling of independence

4. Miss my American cohorts from study abroad

5. Miss my host country friends from host country

$\begin{array}{llll}0 & 1 & 2 & 3 \\ 0 & 1 & 2 & 3 \\ 0 & 1 & 2 & 3 \\ 0 & 1 & 2 & 3 \\ 0 & 1 & 2 & 3\end{array}$

\section{OPEN ENDED COMMENTS (Provided Upon Re-entry)}

Directions: Please answer the following questions:

1. What programs, policies, activities, or services provided to you by your university were most helpful to you in your preparation for study abroad? Please list at least three in the space below:

2. What programs, policies, activities, or services would you like to have offered to you by the university that are not presently offered to help prepare you for the study abroad experience? 
3. To whom did you most frequently go to for help in resolving problems that confronted you? (For example: counselors, advisor, students from US, faculty, family, etc). Please list in order of preference.

\section{Re-Entry Questions:}

4. Have your relations with your family changed since your study abroad? Please briefly describe:

5. Was it an easy transition to return to campus?

6. How are things with your old friends? (Prompt: do you feel disconnected from earlier relationships or have things picked up where you left off?

7. What sort of support would you suggest for re-entry adjustment?

8. Do you feel that your personal values have changed? How? 
9. Please describe your study abroad experience. Would you recommend it to others?

\section{Thank you very much for your participation.}

\section{Would you be willing to participate in a small group discussion} concerning the study abroad experience? If so, please e-mail me at Heinecke@sandiego.edu. 
Appendix B

Dr. John Porter Permission Request 


\section{Les}

University of San Diego

School of Education Loaderchlp Studta

February 28, 2005

Dr. John W. Porter

CEO, Urban Education Alliance

1547 Fall Creek Lane

Ann Arbor, Michigan 48108

Dear Dr. Porter,

1 am a doctoral student at the University of San Diego. The purpose of this letter is to seek your permission to use the Michigan International Student Problem Inventory in my dissertation research. I will be conducting my research with students from both the University of San Diego and the University of Califomia at San Diego. The purpose of this study will be to collect information on the expectations of the acculturative process for students prior to their departure for study abroad and the reality of their expectations upon their return to the United States. Specifically, I will use nine categories of your MISPI to measure the anticipated and actual problems experienced by study abroad students and then compare expectations to reality.

My intention is to modify the MISPI to seek respondent reactions to the categories of orientation, social-personal, living-dining, bealth, religious, host language, student activities, and financial aid.

Thank you for this consideration. 1 would be grateful for any additional information you might suggest in this very interesting research. My aim is to issue the modified survey this Spring Semester 2005. I am most grateful for your assistance.

Very respectfully,

Waiter R. Heinecke

Doctoral Student

560 A Avenue

Coronado, CA 92118

Heineckerosandiego.edu

619-437-1898 
Appendix C

Dr. John Porter Permission Letter 
April 21, 2005

\author{
Jonn W. Porter, Ph.D. \\ Educational Consuliant \\ Highpointe at Stonebridge \\ 5336 Pinnacle Court \\ Ann Arbor, MI 48108-8662 \\ Ph. (734) $944-9922$ \\ Fax (734) 9449921
}

Mr. Walter R. Heinecke

Doctoral Student

560 A Avenue

Coronado, CA 92118

Dear Mr. Heinecke:

I received a letter on April 15,2005, along with accompanying information from the Dean of the College of Education at Eastem Michigan University in regard to your request. I regret you had such difficulty finding me. Please be advised that I do hereby grant you permission to use the Michigan International Student Problem Inventory (MISPI). You are also granted permission to modify the instrument consistent with your reseanch design, but consistent with maintaining the validity and reliability.

As you may know, the original research was conducted on the campus at Michigan State University over 40 years ago. It continues to be gratifying to know that this landmark instrument is still being well received across the nation. Over the past 40 years, over 200 related studies have been reported to my several offices. I have enclosed only a few of the most recent published references that have come to my attention.

I am also enclosing a copy of the original instrument and a copy of the original handbook for your background information.

I thought you might be particularly interested in the doctorial dissertation of $\mathrm{Dr}$. Jing Wang, which I have recently read in its entirety. She defended her dissertation in 2003. A copy of her abstract is enclosed. She is currently a Professor at Alleghany College in Pennsylvania.

Best wishes for a successful completion of your research project. I look forwand to receiving a copy of the results.

Sincerely,

J ghin W. Porter

Enclosures. 
Appendix D

Focus Group Questions 


\section{$\underline{\text { Focus Group Questions }}$}

Study Abroad Questions:

1. What were your pre departure expectations?

2. How did your pre departure expectations compare to the reality of your study abroad experience?

3. What was the most difficult adjustment for you?

4. Describe your re-entry experience?

5. Overall, how did you enjoy your experience? 
Appendix E

Category Compilation 


\section{PRELIMINARY SURVEY INFORMATION}

1. Agreement to participate in survey

2. Provide email address

3. Destination country

4. University/school you will attend in host country

5. Length of study program - semester, year, etc.

6. Does the program have an internship component?

7. Purpose/name of program

8. Living arrangements - dormitory, home stay, etc.

9. Did you attend an orientation for your host country before departing abroad?

10. Type of school you attend - public, private

11. Role in school - student, educator, etc.

12. Highest degree obtained

13. For what degree are you currently studying?

14. Major/degree program

15. Age

16. Gender

17. Home state/country of origin

18. Community - suburban, urban, rural

19. Ethnic group you most identify with

20. Native language

21. Have you ever traveled abroad before this experience?

22. If yes, how many times how many times?

23. If yes, how long were these trips abroad (on average)?

24. Taken courses in the host language?

25. Rate your language performance in the host language

26. Primary reason for participating in the study abroad program

27. How did you learn about the study abroad program? 


\section{SURVEY COMPILATION OF NINE (9) CATEGORIES}

Living and Dining (ld_a/ld_b)

Question Number

1. Taste of food in host country

2. Problems regarding housing

3. Being told where you must live

8

9

10

4. Insufficient clothing

5. Not being able to room with a US student

6 . Not being able to find my way

48

7. Campus location

55

8. Bathroom facilities cause problems

60

9. Distances to classrooms from residences

61

10. Relationship with roommates

62

11. Dietary problems

63

12. Finding a place to live

87

Student Admission/Selection (sas_a/sas_b)

1. Concern about my GPA as a measure of my success

2. Concern about being a foreign student

3. Regulations on student activities

4. Treatment received at social occasions

5. Leisure time activities of host nation students

6. Feeling inferior to others

7. Feeling superior to others

8. Desire to go home early

9. Concern about political discussion

10. Writing term papers

11. Understanding lectures

12. Insufficient personal help from professors

Orientation Services (os_a/os_b)

1. Treatment received during my pre-departure orientation meeting

2. Treatment received during my arrival orientation meeting

3. Not enough time to study

4. Registration for classes at home university

5. Relationship with study abroad advisor

6. Insufficient advice from academic advisor

Question Number

1

5

19

20

28

32

59

78

98

99

101

104

Question Number

2

3

23

26

27

30

7. Being accepted in social groups 47

8. Activities of fellow Americans in host country 72

9. Not being met on arrival in host country 80

10. College orientation was insufficient $\quad 81$

11. Trying to be a student, tourist, and ambassador 82

12. Concern about political discussion 98 
Social-Personal (Emotional and Interpersonal) (sp_a/sp_b)

1. Being in love with someone

2. Fear of large crowd gatherings

3. Relationship of men and women in host country

4. Being lonely

5. Trying to make friends

6. Nervousness

7. Being American

8. Homesickness

9. Activities of fellow Americans in host country

10. Desire to go home early

11. Study abroad program not what I expected

12. Not being at ease in public

Student Activities (sa_a/sa_b)

1. Dating practices of people in host country

2. Host country politics

3 . Host country rules and regulations

4. Host country emphasis on time and promptness

5. Sexual customs in host country

6. Host nation emphasis on sports

7. Attitude of some against American students

8. Host nation emphasis on personal cleanliness

9. Attitude of some about skin color

10. Lack of invitations to visit host country families

11. Opportunities to meet more host nation people

12. Trying to make friends

Health and Safety (hs_a/hs_b)

1. Fear of terrorism

2. Concern about being a foreign student

3. Law enforcement practices of host country

4. Finding adequate health services

5. Fear of anti-American protests

6. Need more time to rest

7. Worried about mental health

8. Global war against terrorism

9. Feeling under tension/stress

10. Service received at health center

11. Health suffering due to academic pace

12. Health suffering due to active social life
Question Number 7

Question Number

88

97

100

Question Number

4

5 
Religious Services (rs_a/rs_b)

1. Insufficient personal-social counseling

2. Religious practices in host country

3. Concern about my religious beliefs

4. Finding a worship group of own faith

5. Christianity in host country

6. Having time to devote to own religion

7. Spiritual versus materialistic values

8. Doubting the value of any religion

9. Accepting differences in great religions

10.Lack of knowledge about host country

11.Confusion about American and host country morals

12. Study abroad spirituality was not what was expected

Host Language (hl_a/hl_b)

1. Speaking the host country language

2. Ability to read the host country language

3. Hard to understand foreign tongue

4. Making presentations in class

5. Understanding lectures in host language

6. Reading textbooks written in host language

7. Understanding host country language

8 . My limited host country vocabulary

9. My pronunciation is not understood

10. Holding conversations with host nation friends

11 Comprehending textbooks in host country language

Financial Aid (Monev Issues) (fa_a/fa_b)

1. Lack of money for travel

2. Not receiving enough money from home

3. Trying to extend stay to travel after studies

4. Cost of buying food

5. Having enough money for social events

6. Limited buying power of US dollar

7. Money for clothing

8. Unexpected financial needs

9. Lack of money to meet expenses

10. Problems with shopping in the host country

11. Cost of traveling abroad

12. Understand the value of study abroad experience

Miscellaneous (m_a/m_b)

1. My physical height and physique

2. Re-entry into the United States

3 . Changes in weather condition
Question Number

103

Question Number

Question Number

Question Number 
Appendix F

Demographics 


\section{Frequencies}

\section{Countries Visited}

\begin{tabular}{|c|c|c|c|c|c|}
\hline & & Frequency & Percent & Valid Percent & $\begin{array}{c}\text { Cumulative } \\
\text { Percent }\end{array}$ \\
\hline \multirow[t]{26}{*}{ Valid } & Australia & 3 & 2.6 & 2.6 & 2.6 \\
\hline & India & 2 & 1.8 & 1.8 & 4.4 \\
\hline & England & 19 & 16.7 & 16.7 & 21.1 \\
\hline & Spain & 24 & 21.1 & 21.1 & 42.1 \\
\hline & China & 5 & 4.4 & 4.4 & 46.5 \\
\hline & Japan & 7 & 6.1 & 6.1 & 52.6 \\
\hline & Scotland & 1 & .9 & .9 & 53.5 \\
\hline & Italy & 11 & 9.6 & 9.6 & 63.2 \\
\hline & Mexico & 4 & 3.5 & 3.5 & 66.7 \\
\hline & Barbados & 2 & 1.8 & 1.8 & 68.4 \\
\hline & Ireland & 9 & 7.9 & 7.9 & 76.3 \\
\hline & France & 6 & 5.3 & 5.3 & 81.6 \\
\hline & Brazil & 1 & .9 & .9 & 82.5 \\
\hline & Egypt & 2 & 1.8 & 1.8 & 84.2 \\
\hline & Singapore & 1 & .9 & .9 & 85.1 \\
\hline & Costa Rica & 1 & .9 & .9 & 86.0 \\
\hline & Chile & 1 & .9 & .9 & 86.8 \\
\hline & Ghana & 1 & .9 & .9 & 87.7 \\
\hline & Switzerland & 1 & .9 & .9 & 88.6 \\
\hline & Argentina & 2 & 1.8 & 1.8 & 90.4 \\
\hline & Portugal & 3 & 2.6 & 2.6 & 93.0 \\
\hline & Peru & 1 & .9 & .9 & 93.9 \\
\hline & Thailand & 2 & 1.8 & 1.8 & 95.6 \\
\hline & $\begin{array}{l}\text { Semester at } \\
\text { Sea }\end{array}$ & 2 & 1.8 & 1.8 & 97.4 \\
\hline & $\begin{array}{l}\text { Northern } \\
\text { Ireland }\end{array}$ & 3 & 2.6 & 2.6 & 100.0 \\
\hline & Total & 114 & 100.0 & 100.0 & \\
\hline
\end{tabular}

\section{Study Abroad Program}

\begin{tabular}{|c|c|c|c|c|c|}
\hline & & Frequency & Percent & Valid Percent & $\begin{array}{l}\text { Cumulative } \\
\text { Percent }\end{array}$ \\
\hline \multirow[t]{5}{*}{ Valid } & semestr & 67 & 58.8 & 58.8 & 58.8 \\
\hline & summer & 15 & 13.2 & 13.2 & 71.9 \\
\hline & year & 29 & 25.4 & 25.4 & 97.4 \\
\hline & other & 3 & 2.6 & 2.6 & 100.0 \\
\hline & Total & 114 & 100.0 & 100.0 & \\
\hline
\end{tabular}


Education Level

\begin{tabular}{|ll|r|r|r|r|}
\hline & & & & Cumulative \\
& & Frequency & Percent & Valid Percent & Percent \\
\hline Valid & high & 104 & 91.2 & 91.2 & 91.2 \\
& school/GED & 1 & .9 & .9 & 92.1 \\
& masters & 6 & 5.3 & 5.3 & 97.4 \\
& AA & 3 & 2.6 & 2.6 & 100.0 \\
BAVBS & 114 & 100.0 & 100.0 & \\
\hline
\end{tabular}

Age

\begin{tabular}{|ll|r|r|r|r|}
\hline & & & & \multicolumn{2}{c|}{$\begin{array}{c}\text { Cumulative } \\
\text { Percent }\end{array}$} \\
\hline Valid & 19 & 19 & 16.7 & 16.7 & 16.7 \\
& 2 & 1 & .9 & .9 & 17.5 \\
& 20 & 64 & 56.1 & 56.1 & 73.7 \\
21 & 21 & 18.4 & 18.4 & 92.1 \\
22 & 3 & 2.6 & 2.6 & 94.7 \\
23 & 2 & 1.8 & 1.8 & 96.5 \\
25 & 1 & .9 & .9 & 97.4 \\
28 & 1 & .9 & .9 & 98.2 \\
41 & 1 & .9 & .9 & 99.1 \\
43 & 1 & .9 & .9 & 100.0 \\
Total & 114 & 100.0 & 100.0 & \\
\hline
\end{tabular}

\section{Gender}

\begin{tabular}{|c|c|c|c|c|c|}
\hline & & Frequency & Percent & Valid Percent & $\begin{array}{c}\text { Cumulative } \\
\text { Percent }\end{array}$ \\
\hline \multirow[t]{3}{*}{ Valid } & female & 96 & 84.2 & 84.2 & 84.2 \\
\hline & male & 18 & 15.8 & 15.8 & 100.0 \\
\hline & Total & 114 & 100.0 & 100.0 & \\
\hline
\end{tabular}


Home State

\begin{tabular}{|l|r|r|r|r|}
\hline & & & & Cumulative \\
Percent
\end{tabular}

Ethnicity

\begin{tabular}{|c|c|c|c|c|c|}
\hline & & Frequency & Percent & Valid Percent & $\begin{array}{c}\text { Cumulative } \\
\text { Percent }\end{array}$ \\
\hline \multirow[t]{7}{*}{ Valid } & Caucasian & 77 & 67.5 & 67.5 & 67.5 \\
\hline & Asian & 23 & 20.2 & 20.2 & 87.7 \\
\hline & European & 5 & 4.4 & 4.4 & 92.1 \\
\hline & $\begin{array}{l}\text { Middle } \\
\text { Eastern }\end{array}$ & 1 & .9 & .9 & 93.0 \\
\hline & Hispanic & 6 & 5.3 & 5.3 & 98.2 \\
\hline & $\begin{array}{l}\text { Pacific } \\
\text { Islander }\end{array}$ & 2 & 1.8 & 1.8 & 100.0 \\
\hline & Total & 114 & 100.0 & 100.0 & \\
\hline
\end{tabular}

Travel Experience

\begin{tabular}{|c|c|c|c|c|c|}
\hline & & Frequency & Percent & Valid Percent & $\begin{array}{c}\text { Cumulative } \\
\text { Percent }\end{array}$ \\
\hline \multirow[t]{3}{*}{ Valid } & 1 & 81 & 71.1 & 71.1 & 71.1 \\
\hline & 2 & 33 & 28.9 & 28.9 & 100.0 \\
\hline & Total & 114 & 100.0 & 100.0 & \\
\hline
\end{tabular}


Native Language

\begin{tabular}{|c|c|c|c|c|c|}
\hline & & Frequency & Percent & Valid Percent & $\begin{array}{c}\text { Cumulative } \\
\text { Percent }\end{array}$ \\
\hline \multirow[t]{14}{*}{ Valid } & English & 165 & 85.1 & 85.1 & 85.1 \\
\hline & Korea & 5 & 2.6 & 2.6 & 87.6 \\
\hline & Spanish & 5 & 2.6 & 2.6 & 90.2 \\
\hline & Arabic & 5 & 2.6 & 2.6 & 92.8 \\
\hline & Mandarin & 4 & 2.1 & 2.1 & 94.8 \\
\hline & $\begin{array}{l}\text { Cantones } \\
\mathrm{e}\end{array}$ & 1 & .5 & .5 & 95.4 \\
\hline & Japanese & 1 & .5 & .5 & 95.9 \\
\hline & 11 & 1 & .5 & .5 & 96.4 \\
\hline & 12 & 2 & 1.0 & 1.0 & 97.4 \\
\hline & 19 & 1 & .5 & .5 & 97.9 \\
\hline & 20 & 2 & 1.0 & 1.0 & 99.0 \\
\hline & 21 & 1 & .5 & .5 & 99.5 \\
\hline & 22 & 1 & .5 & .5 & 100.0 \\
\hline & Total & 194 & 100.0 & 100.0 & \\
\hline
\end{tabular}

a20_travexp

\begin{tabular}{|c|c|c|c|c|c|}
\hline & & Frequency & Percent & Valid Percent & $\begin{array}{c}\text { Cumulative } \\
\text { Percent }\end{array}$ \\
\hline \multirow[t]{23}{*}{ Weeks } & 0 & 55 & 28.4 & 28.4 & 28.4 \\
\hline & 1 & 19 & 9.8 & 9.8 & 38.1 \\
\hline & 10 & 3 & 1.5 & 1.5 & 39.7 \\
\hline & 100 & 3 & 1.5 & 1.5 & 41.2 \\
\hline & 12 & 3 & 1.5 & 1.5 & 42.8 \\
\hline & 15 & 1 & .5 & .5 & 43.3 \\
\hline & 18 & 1 & .5 & .5 & 43.8 \\
\hline & 2 & 37 & 19.1 & 19.1 & 62.9 \\
\hline & 20 & 2 & 1.0 & 1.0 & 63.9 \\
\hline & 24 & 2 & 1.0 & 1.0 & 64.9 \\
\hline & 3 & 27 & 13.9 & 13.9 & 78.9 \\
\hline & 30 & 1 & .5 & .5 & 79.4 \\
\hline & 32 & 1 & .5 & .5 & 79.9 \\
\hline & 4 & 14 & 7.2 & 7.2 & 87.1 \\
\hline & 40 & 1 & .5 & .5 & 87.6 \\
\hline & 48 & 1 & .5 & .5 & 88.1 \\
\hline & 5 & 3 & 1.5 & 1.5 & 89.7 \\
\hline & 56 & 1 & .5 & .5 & 90.2 \\
\hline & 6 & 10 & 5.2 & 5.2 & 95.4 \\
\hline & 60 & 1 & .5 & .5 & 95.9 \\
\hline & 8 & 5 & 2.6 & 2.6 & 98.5 \\
\hline & 96 & 3 & 1.5 & 1.5 & 100.0 \\
\hline & Total & 194 & 100.0 & 100.0 & \\
\hline
\end{tabular}


Housing

\begin{tabular}{|c|c|c|c|c|c|}
\hline & & Frequency & Percent & Valid Percent & $\begin{array}{c}\text { Cumulative } \\
\text { Percent }\end{array}$ \\
\hline \multirow[t]{4}{*}{ Valid } & dorm & 88 & 45.4 & 45.4 & 45.4 \\
\hline & family & 67 & 34.5 & 34.5 & 79.9 \\
\hline & communit & 39 & 20.1 & 20.1 & 100.0 \\
\hline & Total & 194 & 100.0 & 100.0 & \\
\hline
\end{tabular}

